\title{
Actions of pituitary hormones beyond traditional targets
}

\author{
Mone Zaidi', Maria I New1', Harry C Blair2, Alberta Zallone², Ramkumarie Baliram', Terry F Davies', \\ Christopher Cardozo', James Iqbal', Li Sun', Clifford J Rosen ${ }^{4}$ and Tony Yuen'
}

1The Mount Sinai Bone Program, Department of Medicine, Icahn School of Medicine at Mount Sinai, New York, New York, USA

2The Pittsburgh VA Medical Center and Departments of Pathology and of Cell Biology, University of Pittsburgh School of Medicine, Pittsburgh,

Pennsylvania, USA

${ }^{3}$ Department of Histology, University of Bari, Bari, Italy

${ }^{4}$ Maine Medical Center Research Institute, Scarborough, Maine, USA

Correspondence should be addressed to M Zaidi: mone.zaidi@mssm.edu

\begin{abstract}
Studies over the past decade have challenged the long-held belief that pituitary hormones have singular functions in regulating specific target tissues, including master hormone secretion. Our discovery of the action of thyroid-stimulating hormone (TSH) on bone provided the first glimpse into the non-traditional functions of pituitary hormones. Here we discuss evolving experimental and clinical evidence that growth hormone (GH), follicle-stimulating hormone (FSH), adrenocorticotrophic hormone (ACTH), prolactin, oxytocin and arginine vasopressin (AVP) regulate bone and other target tissues, such as fat. Notably, genetic and pharmacologic FSH suppression increases bone mass and reduces body fat, laying the framework for targeting the FSH axis for treating obesity and osteoporosis simultaneously with a single agent. Certain 'pituitary' hormones, such as TSH and oxytocin, are also expressed in bone cells, providing local paracrine and autocrine networks for the regulation of bone mass. Overall, the continuing identification of new roles for pituitary hormones in biology provides an entirely new layer of physiologic circuitry, while unmasking new therapeutic targets.
\end{abstract}
Key Words
- follicle-stimulating hormone
- adrenocorticotropic hormone
- growth hormone
- oxytocin
vasopressin

\section{Introduction}

It has become increasingly clear that pituitary hormones that have traditionally been seen as regulators of single bodily processes, including endocrine functions, have additional roles in physiology. The global deletion of these hormones or their receptors in mice has yielded unexpected skeletal and metabolic phenotypes, which have been confirmed through traditional pharmacologic approaches (Zaidi 2007). Initial reports showed that thyroid-stimulating hormone receptors (TSHRs) were expressed on bone cells and that their haploinsufficiency in $\mathrm{Tshr}^{+/}$- mice caused osteopenia without affecting the thyroid function (Abe et al. 2003). Likewise, receptors for follicle-stimulating hormone (FSHRs) are expressed in both skeletal cells and adipose tissue, where they regulate body composition (Sun et al. 2006, Liu et al. 2015, 2017, Feng et al. 2017). However, due to feedback circuitry, it has often been difficult to tease out specific actions of pituitary hormones on these newly described targets from known actions of the hormones they produce (Blair et al. 2011). With emerging evidence for such additional roles of pituitary hormones in integrative physiology, new avenues for therapy have been unmasked (Liu et al. 2017). In this review, we discuss these newly discovered actions of pituitary hormones and their physiologic and therapeutic relevance. 


\section{Evolutionary considerations}

The most obvious example of a pituitary hormone being part of a widely distributed G-protein-coupled receptor (GPCR) system is adrenocorticotropic hormone (ACTH), known to participate in cell differentiation in several contexts. This distributed function is nonetheless overshadowed by its pituitary-adrenal signaling function. Tissue-specific, regulated proteolytic processing of a single large prohormone, proopiomelanocortin (POMC), yields ligands that act on five melanocortin receptors (MC1R - MC5R), including the ACTH receptor (MC2R), which regulates cellular functions such as pigment production, appetite and sexual function. While ACTH is the predominant product in the anterior pituitary, three melanotropins and $\beta$-endorphin are synthesized from the same precursor at other sites (Blair et al. 2011). There are reports of ACTH production by human macrophages/ monocytes (Pallinger \& Csaba 2008), making it possible that MC2Rs in bone may be activated by local, instead of pituitary-derived ACTH (Fig. 1). Abundant expression of the MC2R has also been documented in bone-forming units in adult mice (Isales et al. 2010). Similar to its action in the vertebrate adrenal cortex, ACTH acts on osteoblastic MC2Rs to induce the expression of vascular endothelial growth factor (VEGF) (Zaidi et al. 2010) (Fig. 1). This is the likely basis of ACTH action in preventing glucocorticoidinduced osteonecrosis, as assessed in a rabbit model (Zaidi et al. 2010).
TSH and FSH, together with chorionic gonadotropin (CG) and luteinizing hormone (LH), are a group of heterodimeric proteins that share a common $\alpha$-chain, with their differing $\beta$-chains determining specificity. These hormones are particularly interesting in that simpler phyla have distributed functions. In the primitive nervous system of coelenterates, which have no endocrine glands, a TSHR family gene is expressed widely and shows the intron-exon structure found in mammals (Vibede et al. 1998). In bony fish, abundant TSHR is expressed in the thyroid, but the receptor is also detectable in ovaries, heart, muscle and brain (Kumar et al. 2000). Fish gonads also express the LH/CG receptor (LHCGR) and FSH receptor (FSHR), with multiple differently processed forms of the FSHR that bind both FSH and LH (Bogerd et al. 2005, Kobayashi \& Andersen 2008). Low-level expression of the FSHR and TSHR has been reported in the spleen and bone marrow, respectively (Kumar et al. 2001, Vincent et al. 2009).

\section{TSH and bone mass regulation}

In 2003, Abe and coworkers documented direct actions of TSH on bone that were independent of thyroid hormones (Abe et al. 2003, Novack 2003). Three key findings separated the known action of high thyroid hormone on bone from the newly identified TSH effects. First, TSHR haploinsufficiency in heterozygotic $\mathrm{Tshr}^{-/-}$mice was found to yield an osteoporotic phenotype with increased

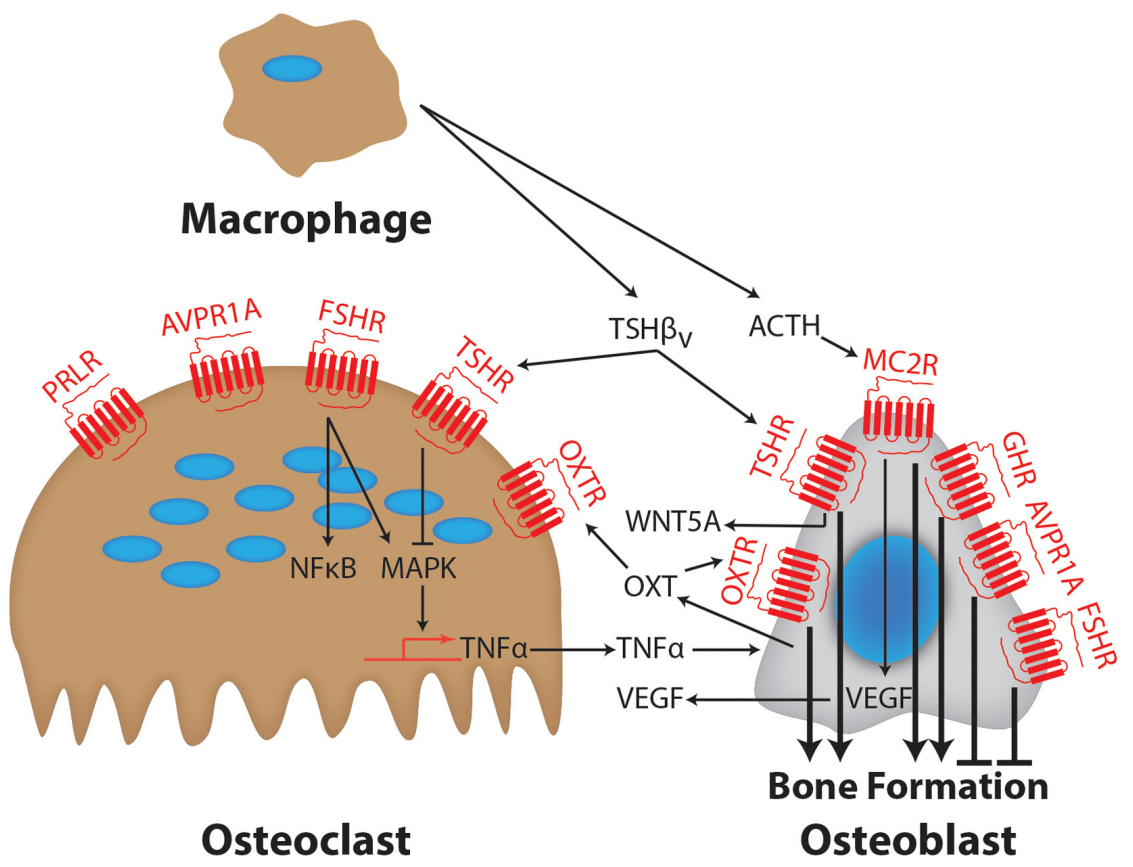

\section{Figure 1}

Endocrine control of bone remodeling. Bone formation is regulated by signals from pituitary hormones. GH, ACTH, FSH, TSH, PRL, OXT and AVP regulate both osteoclasts and osteoblasts directly through GPCRs. Certain ligands, namely OXT, TSH $\beta_{v}$ and ACTH, are also produced in bone marrow by macrophages and/or osteoblasts. 
osteoclast formation ex vivo, while thyroid hormone levels remained unchanged. Second, the osteoporosis noted in Tshr-null mice could not be explained by low thyroid hormone levels, as high, rather than low levels have been implicated in bone loss. Third, and importantly, skeletal runting, but not the osteoporotic phenotype, was reversed by thyroid hormone replacement that rendered $T s h r^{-/-}$ mice euthyroid (Abe et al. 2003).

The idea therefore emerged that TSH acted on bone independently of thyroid hormones, and that the osteoporosis of hyperthyroidism may, in part, result from low TSH (Zaidi et al. 2006). This latter hypothesis was studied in wild-type and Tshr- ${ }^{-}$mice that were rendered either euthyroid or hyperthyroid by implanting thyroxine (T4) pellets (Baliram et al. 2012). Hyperthyroid Tshr-- mice suffered greater bone loss than wild-type mice that were equally hyperthyroid (Baliram et al. 2012). This suggested that absent TSH signaling in Tshr-/- mice itself contributes to hyperthyroid bone loss.

Consistent with the high-turnover osteoporosis seen in hyperthyroidism, Tshr-- mice and hyt/hyt mice, in which the TSH receptor is naturally defective, showed evidence of increased osteoclast formation (Britto et al. 1994, Sun et al. 2008). Studies further showed that recombinant TSH attenuated the genesis, function and survival of osteoclasts in vitro (Abe et al. 2003, Ma et al. 2009). Accordingly, osteoclastogenesis was inhibited when the constitutively activated TSHR was overexpressed in osteoclast precursors or an activating TSHR antibody was injected (Hase et al. 2006, Sun et al. 2008, Ma et al. 2011). Human data for a direct action of TSH on bone is equally compelling - a single subcutaneous injection of recombinant human TSH lowered serum C-terminal telopeptide (CTX) in postmenopausal women within 2 days (Mazziotti et al. 2005). In no instance of TSH replacement did thyroid hormones increase. We also know that these anti-osteoclastogenic actions of TSH are mediated by reduced nuclear factor kappa-light-chainenhancer of activated B cells (NF- $\mathrm{kB}$ ) and Janus N-terminus kinase (JNK) activation, as well as indirectly, through diminished tumor necrosis factor $\alpha(\mathrm{TNF} \alpha)$ production (Abe et al. 2003, Hase et al. 2006). The effect of TSH on TNF $\alpha$ synthesis is mediated transcriptionally by binding of two high-mobility group box proteins, HMGB1 and HMGB2, to the Tnfo gene promoter (Yamoah et al. 2008). Thus, TNF $\alpha$ production is upregulated in osteoporotic Tshr-1- mice (Abe et al. 2003), and the genetic deletion of Tnfo in these mice reverses the osteoporosis and the bone remodeling defects, proving that the Tshr-/- phenotype is mediated by TNF $\alpha$, at least in part (Sun et al. 2013).
TSH inhibits osteoblastogenesis in bone marrowderived cell cultures (Abe et al. 2003), but stimulates osteoblast differentiation and mineralization in murine ES cell cultures through a wingless integration 5A- (WNT5A-) dependent mechanism (Baliram et al. 2011). In vivo, intermittently administered TSH is anabolic in both rats and mice (Sampath et al. 2007, Sun et al. 2008). Thus, when injected at intervals as far apart as every two weeks into rats, TSH rescues the bone loss, 28 weeks following ovariectomy (Sun et al. 2008). Calcein-labeling studies are consistent with a direct bone-forming action of intermittent TSH (Sampath et al. 2007). Consistent with rodent data, Martini et al. show an increase in procollagen type I N-terminal propeptide (PINP), a marker of bone formation, validating the conclusion that a bolus dose of TSH is indeed anabolic in people (Martini et al. 2008). Likewise, antibody-activated TSH signaling contributes to high bone formation, independent of the actions of thyroid hormone (Cho et al. 2015).

Epidemiological studies in an increasing number of global cohorts document a tight relationship between low TSH levels, parameters of bone loss and even fracture risk. In fact, 4.5- and 3.2-fold increases in the risk of vertebral and non-vertebral fractures, respectively, were noted at serum TSH levels $<0.1 \mathrm{IU} / \mathrm{L}$ (Bauer et al. 2001). There was also a strong negative correlation between low serum TSH and high CTX levels, independently of thyroid hormone levels (Zofkova \& Hill 2008). Greater bone loss was also seen in patients on L-thyroxine that had suppressed TSH levels than in those without such suppression (La Vignera et al. 2008, Baqi et al. 2010, Flynn et al. 2010, Kim et al. 2015). These observations were supported by the Tromsø Study, in which participants with serum TSH $<2$ SD had a significantly lower bone mineral density (BMD), those with TSH above 2 SD had a significantly increased BMD, whereas there was no association between TSH and BMD at normal TSH levels (Grimnes et al. 2008). Serum levels of cathepsin $\mathrm{K}$, a surrogate resorption marker, were also elevated in thyroid cancer patients on suppressive therapy (Mikosch et al. 2008). Concordant with this, the second Nord-Trøndelag Health Study in 1995-97 (HUNT 2) found a positive correlation between serum TSH and BMD at the distal forearm (Svare et al. 2009). In fact, it is now evident that in patients with elevated TSH levels, longterm fracture risk is related to the cumulative duration of periods with low TSH resulting from excessive thyroid hormone replacement (Abrahamsen et al. 2015). In Odense Patient data Explorative Network Thyroid Status and Register Outcomes (OPENTHYRO), fracture risk was a function of the duration of hyperthyroidism (Abrahamsen 
et al. 2014). Likewise, TSH suppression increased the risk of postoperative osteoporosis in low- and intermediaterisk thyroid cancer patients (Wang et al. 2015c). Even hypothyroid patients requiring thyroid hormone therapy often displayed reduced BMD that correlated with low TSH levels (Christy et al. 2014, Karimifar et al. 2014).

The National Health and Nutrition Examination Survey (NHANES) has further shown that the odds ratio for correlations between TSH and bone mass ranged between 2 and 3.4 (Morris 2007). Elderly women with low-normal TSH levels (in the euthyroid range) have lower BMDs with or without weaker femoral structures (Ding et al. 2016, Lee et al. 2016). Such women also have a high vertebral fracture risk, independent of age, BMD and thyroid hormones (Mazziotti et al. 2010). Consistent with these data, there is a positive correlation between serum TSH and BMD in women with postmenopausal osteoporosis; in one of these studies, serum TSH was associated with osteoprotection in a regression model (van Rijn et al. 2014, Noh et al. 2015, Acar et al. 2016). In elderly men, lower TSH levels within the normal range were associated with an approximately 30\% increase in the risk of hip fracture (Waring et al. 2013). Finally, genetic evidence supports the epidemiologic data for a role of TSH in human bone physiology. Patients harboring the TSHRD727E polymorphism have high bone mass (Albagha et al. 2005, Heemstra et al. 2008, van der Deure et al. 2008, Liu et al. 2012).

\section{FSH and mechanisms of bone loss}

FSH acts on an FSHR in the osteoclasts and directly stimulates bone resorption (Sun et al. 2006). Supporting this conclusion, mice haploinsufficient in FSH $\beta$ showed reduced bone resorption and increased bone mass, while ovarian function remained preserved (Sun et al. 2006). Several studies have now confirmed direct effects of FSH on the skeleton in rodents and humans. The exogenous administration of FSH to rats was found to augment ovariectomy-induced bone loss, and an FSH antagonist reduced bone loss after ovariectomy or FSH injection (Liu et al. $2010 a, b)$.

In women, hypergonadotropic amenorrhea (serum FSH $\sim 35$ IU/L) was found to be associated with greater bone loss than in hypogonadotropic amenorrhea ( 8 IU/L) (Devleta et al. 2004). Likewise, women with functional hypothalamic amenorrhea, wherein both FSH and estrogen are low, showed slight-to-moderate skeletal defects (Podfigurna-Stopa et al. 2012). This is contrast to luperide, which has not been shown to prevent hypogonadal hyper-resorption, wherein the acute loss of estrogen appears not to be compensated by reduced FSH levels (Drake et al. 2010). However, genetic evidence points to the function of FSHRs in human pathophysiology. Women harboring an activating FSHR ${ }^{N 680 S}$ polymorphism have been shown to display lower bone mass and high resorption markers (Rendina et al. 2010). Furthermore, digenic combinations between wild-type genotype of the 3'UTR marker for the aromatase (CYP19A1) gene, the IVS4 marker of the same gene and the bone morphogenetic protein 15 (BMP15) and FSHR genes have been described as being osteoprotective (Mendoza et al. 2012). Together, these latter studies attest to a modulatory function for $\mathrm{FSH}$, in addition to that of estrogen, in human skeletal physiology and a permissive role in the pathophysiology of postmenopausal osteoporosis.

The most impressive clinical correlations between bone loss and serum FSH levels are seen in Study of Women's Health across the Nations (SWAN), a longitudinal cohort of 2375 perimenopausal women. Not only was there a strong correlation between serum FSH levels and markers of bone resorption, a change in FSH levels over 4 years predicted decrements in bone mass (Sowers et al. 2003). Data from a cohort of Chinese women showed similar trends, notably a significant association between bone loss and high serum FSH (Xu et al. 2009, Wu et al. 2010). Furthermore, in another cohort of southern Chinese women aged between 45 and 55 years, those in the highest quartile of serum FSH lost bone at a 1.3- to 2.3fold higher rate than those in the lowest quartile (Cheung et al. 2011). A more recent analysis of perimenopausal Chinese women aged between 45 and 50 years revealed a strong correlation between serum CTX and FSH levels (Wang et al. 2015a). Importantly, CTX levels were greater when serum FSH levels were $>40$ IU/L (Wang et al. 2015a). The NHANES III cohort with women between 42 and 60 years likewise showed a strong correlation between serum FSH and femoral neck BMD (Gallagher et al. 2010). Serum osteocalcin and CTX were also positively correlated with serum FSH, but not with estradiol in a crosssectional study of 92 postmenopausal women (GarciaMartin et al. 2012). The bone turnover range of normality (BONTURNO) study group similarly showed that women with serum FSH levels > 30 IU/L had significantly higher bone turnover markers than age-matched women, despite having normal menses (Adami et al. 2008). Consistent with this, lower serum FSH levels and higher serum 
estrogen levels have been associated with lower rates of lumbar spine bone loss during phases of the menopausal transition (Crandall et al. 2013).

Mechanistically, FSH increases osteoclast formation, function and survival through a distinct FSHR isoform (Sun et al. 2006, Wu et al. 2007, Robinson et al. 2010, Sun et al. 2010, Wang et al. 2015b). Failures to identify FSHRs on osteoclasts likely used primers targeted to the ovarian isoform (Ritter et al. 2008, Allan et al. 2010). We very consistently find FSHR in human $\mathrm{CD} 14^{+}$cells and osteoclasts using nested primers and sequencing to verify the specificity of the reaction and amplifying regions that contain an intron to avoid the pitfall of genomic DNA contamination (Robinson et al. 2010, Tourkova et al. 2015). Cellular responsiveness to FSH also appears to be determined by the level of FSH glycosylation (Meher $e t$ al. 2015), with the prediction that the fully glycosylated isoform is more active on the bone FSHR. With that said, FSHR expression in bone has recently been firmly established through in vivo imaging of FSH binding in live mice (Feng et al. 2017). A small near-infrared fluorophore CH1055 conjugated to FSH was injected into live mice, followed by capture of infrared signals upon binding to its receptor in ovaries, testes and bone in vivo (Feng et al. 2017).

The osteoclastogenic response to FSH was interestingly abolished in mice lacking immunoreceptor tyrosinebased activation motif (Itam) adapter signaling molecules (Wu et al. 2007). This latter study suggests an interaction between FSH and immune receptor complexes, although the significance of this remains unclear. In a separate study, FSH enhanced the expression of receptor activator of nuclear factor kappa B (RANK) (Cannon et al. 2011). In addition, FSH indirectly stimulated osteoclast formation by releasing osteoclastogenic cytokines, namely interleukin $1 \beta$ (IL1B), TNF $\alpha$ and interleukin 6 (IL6) in proportion to the surface expression of FSHRs (Iqbal et al. 2006, Cannon et al. 2010). In a study of 36 women between the ages of 20 and 50 years, serum FSH levels correlated with circulating cytokine concentrations (Cannon et al. 2010, Gertz et al. 2010). Gourlay et al. in contrast failed to show a relationship between bone mass and FSH or, indeed, estrogen (Gourlay et al. 2011). Interestingly, the same authors documented an independent correlation between FSH and lean mass (Gourlay et al. 2012).

Despite accumulating evidence for separate actions of $\mathrm{FSH}$, it has been difficult to tease out the action of FSH from that of estrogen in vivo, as FSH releases estrogen, and the actions of FSH and estrogen on the osteoclast are opposed. The injection of FSH into mice with intact ovaries (Ritter et al. 2008) or its transgenic overexpression (Allan et al. 2010), even in hpg mice, is therefore unlikely to reveal pro-resorptive actions of FSH. This is because direct effects of FSH on the osteoclast will invariably be masked by the anti-resorptive and anabolic actions of the ovarian estrogen so released in response to FSH. However, there is evidence that women with low FSH levels undergo less bone loss (Devleta et al. 2004) and that the effectiveness of estrogen therapy is related to the degree of FSH suppression (Kawai et al. 2004).

Rapid and profuse bone loss begins three years prior to the last menstrual period, when serum estrogen is relatively normal and FSH levels are rising (Randolph et al. 2003). This is when the rate of bone loss is maximal, and therefore cannot be attributed to changes in serum estrogen (Randolph et al. 2003, Sowers et al. 2003). To address the importance of FSH elevations in this period, Lukefahr and coworkers examined bone loss using a unique rat model of the perimenopausal transition (Lukefahr et al. 2012). This model, in which the ovotoxin 4 -vinylcyclohexene diepoxide (VCD) is administered to rats, was characterized by a prolonged estrogen-replete period when serum FSH levels were elevated. Longitudinal measurements revealed that significant decreases in BMD (5-13\%) occurred during periods of increased FSH and decreased inhibins (Lukefahr et al. 2012).

To leverage this selective increase in FSH early in the menopausal transition, an antibody to a 13-amino-acidlong peptide sequence within the receptor-binding domain of the FSH $\beta$-subunit was generated (Zhu et al. 2012a,b). The FSH antibody bound FSH specifically and blocked its action on osteoclast formation in vitro. When injected into ovariectomized mice, the FSH antibody attenuated bone loss not only by inhibiting bone resorption, but also by stimulating bone formation, an action we had failed to detect in the knockout models (Sun et al. 2006, Zhu et al. 2012a,b). Notably, stromal cells isolated from mice treated with the FSH antibody showed greater osteoblast precursor colony counts, similar to stromal cells isolated from Fshr ${ }^{-1-}$ mice (Zhu et al. 2012a). This suggested that FSH negatively regulates osteoblast differentiation via signaling-efficient FSHRs present on mesenchymal stem cells (Zhu et al. 2012a). There is recent direct evidence for FSH action on osteoblast precursors, albeit in the opposite direction (Su et al. 2017). Overall, the data prompt the future development of a novel FSH-blocking agent as a means of uncoupling bone formation and bone resorption to a therapeutic advantage in people. An interesting alternative strategy, for which a proof-of-principle study is available, is the use of an FSH $\beta$ vaccine. It has been shown 
that immunizing ovariectomized rats with the GST-FSH $\beta$ antigen significantly prevents trabecular bone loss and increases bone strength (Geng et al. 2013).

\section{GH in skeletal maturation}

Growth hormone (GH) has for long been known to play a key role in chondrocyte and bone cell function, and thereby to modulate skeletal growth and modeling. While a GHR is expressed in osteoblasts, GH appears to exert an action via its release of insulin-like growth factors (IGFs). IGF1, the predominant growth factor, is synthesized mainly in the liver and $80 \%$ of the circulating form is bound to IGF-binding protein-3 (IGFBP3) and the acid labile subunit (ALS). Growth retardation and osteoporosis are phenotypic hallmarks in $\mathrm{Ghr}^{-1-}$ mice (De Jesus et al. 2009) and dwarfism in Laron syndrome, which is due to loss-of-function mutations in the GHR gene, is associated with osteoporosis (Laron 1999, Laron et al. 1999). However, the Ghr-/- phenotype is compensated by the overexpression of IGF1 and mice lacking both liver IGF1 (LID) and ALS, with depleted serum IGF1, show reduced bone growth and bone strength in the face of high circulating GH levels (Yakar et al. 2002). While these results suggest that the skeletal effects of $\mathrm{GH}$ require IGF1, there is equally compelling evidence that GH can act independently of IGF. In ovariectomized LID mice, for example, GH reverses osteopenia (Fritton et al. 2010). Furthermore, GH replacement reverses the increased adiposity in hypophysectomized rats, while IGF1 replacement does not (Menagh et al. 2010). Together, the latter findings not only point to a direct action of GH on bone, but also extend GH actions to the control of adiposity (see below).

\section{Pituitary hormones and intergenerational calcium transfer}

A major function of the skeleton is to serve as a source for calcium ions that would mineralize the fetal skeleton during pregnancy and allow for bone growth and modeling during lactation. Both phases are characterized by excessive maternal bone resorption that has been thought to result from a combination of hypoestrogenemia and parathyroid hormone-related protein (PTHrP) production by the breast tissue (Wysolmerski 2002). Despite the loss of the maternal skeleton, with noted reductions in $\mathrm{BMD}$ in the region of $1-2 \%$ per month, this bone loss is near-completely reversed upon weaning (Sowers et al. 1995). The mechanism of the latter effect is unclear; however, ineffective skeletal restoration, for example, over multiple pregnancies, can lead to pregnancy- and lactation-associated osteoporosis.

Plasma OXT levels peak during late pregnancy and lactation. In addition to its action on milk ejection, uterine contraction, social behavior and feeding, OXT acts on a GPCR present in abundance on osteoblasts, osteoclasts and their precursors (Argiolas et al. 1988, Insel \& Harbaugh 1989, Nishimori et al. 1996, Young et al. 1998, Copland et al. 1999, Colucci et al. 2002, Mantella et al. 2003, Sclafani et al. 2007, Tamma et al. 2009). Bone marrow cells also synthesize OXT, suggesting the existence of autocrine and paracrine interactions (Tamma et al. 2009, Colaianni et al. 2011).

OXT has been shown to stimulate osteoblast differentiation and bone formation in mice (Colucci et al. 2002, Elabd et al. 2008, Tamma et al. 2009), and $\mathrm{Oxt}^{-/-}$and $\mathrm{Oxtr}^{-/-}$mice, importantly normally lactating heterozygotes, display severe osteoporosis due to a bone-forming defect (Tamma et al. 2009). Systemic OXT injections into wild-type rodents stimulate bone formation, increase bone mass and enhance osseointegration of titanium implants, again attesting to the skeletal anabolic action of OXT (Elabd et al. 2007, Tamma et al. 2009, Wang et al. 2016). These pro-osteoblastic actions are mediated, at least in part, via the nuclear localization of the OXTR following its activation by OXT and, unlike actions on social behavior and feeding, are not mediated centrally (Tamma et al. 2009, Di Benedetto et al. 2014). Thus, short-term intracerebroventricular OXT does not affect bone turnover markers.

In contrast to the potent osteoblastic actions of OXT, its overall effects on bone resorption in vivo appear minimal. OXT stimulates osteoclastogenesis, but inhibits the activity of mature osteoclasts (Tamma et al. 2009). While these pro-osteoclastogenic actions may contribute to intergenerational calcium transfer, the anabolic effect is likely to facilitate restoration of the maternal skeleton. Testifying to this, $\mathrm{Oxt}^{-/-}$pups show hypomineralized skeletons, and $\mathrm{Oxt}^{-/-}$moms display reduced bone formation markers (Liu et al. 2009).

Estrogen positively regulates osteoblastic OXT production and OXTR expression, and the respective actions are synergistic through a local feed-forward loop (Zallone 2006, Colaianni et al. 2012). In postmenopausal women, serum OXT correlates strongly with BMD, particularly at the hip, in the 6-year-long prospective Opsumit Users (OPUS) study (Breuil et al. 2014). Likewise, 
in a cross-sectional study in women aged between 18 and 45 years, plasma OXT levels were correlated with spine and hip BMD and buckling ratio at the hip (Schorr et al. 2017). Low serum OXT levels, in contrast, are associated with severe osteoporosis, independently of estrogen (Breuil et al. 2011). In separate studies, the low nocturnal OXT secretion in amenorrheic athletes is associated with site-dependent microarchitectural deterioration (Lawson et al. 2013). However, in men, the Montceau les Mines Osteoporosis (MINOS) study confirms a lack of association between serum OXT and BMD, bone turnover rate or prevalent fracture (Breuil et al. 2015). Likewise, in mice and rabbits, OXT reverses ovariectomy-, but not orchiectomyinduced bone loss (Beranger et al. 2014, 2015, Qiu et al. 2015). The findings together emphasize possible sex differences that might arise from the regulation of OXT action by estrogen (Colaianni et al. 2012).

Excessive secretion of prolactin (PRL) is also associated with accelerated bone turnover and osteoporosis in hyperprolactinemic states (Naylor et al. 2000). Antagonism of PRL by bromocriptine, a dopamine agonist, reverses the bone loss (Lotinun et al. 2003). It has also long been speculated that, in addition to its permissive role during lactation and suppression folliculogenesis and libido, PRL increases calcium bioavailability for both milk production and fetal skeletalogenesis by promoting skeletal mobilization (Lotinun et al. 1998). This pro-resorptive action has traditionally been thought to arise due to the accompanying hypoestrogenemia (Meaney et al. 2004). However, osteoblasts express PRL receptors (PRLRs) (Coss et al. 2000), suggesting that reduced osteoblastic bone formation may also play a significant role in the bone loss. The pattern of this bone loss is also distinct from that of ovariectomized rodents, where there is evidence for increased bone resorption and formation, with resorption exceeding formation. In contrast, in PRL-exposed rats there is a decoupling between the two processes with increases in bone resorption that are not accompanied by reduced bone formation (Seriwatanachai et al. 2008b). Consistent with this phenotype, PRL decreases osteoblast differentiation markers, in part, through the phosphoinositide 3-kinase (PI3K) signaling pathway (Seriwatanachai et al. 2008a,b). Osteoclasts themselves do not possess PRLRs, and PRL displays indirect pro-resorptive effects by increasing the RANK ligand/osteoprotegerin (RANKL/OPG) ratio (Coss et al. 2000, Seriwatanachai et al. 2008b).

There is also evidence that the effect of PRL on bone depends on the biological maturity of the organism. In infant rats, PRL causes net bone gain and increased osteocalcin expression (Krishnamra \& Seemoung 1996). Likewise, in fetal human osteoblasts, PRL decreases the RANKL/OPG ratio (Seriwatanachai et al. 2008a). These studies point to a role for PRL in bone growth and mineralization in utero, while accelerating bone resorption from the maternal skeleton for intergenerational calcium transfer. Further insight is needed to clarify the role of PRL in bone metabolism and determine the cellular pathways.

\section{AVP and bone loss in hyponatremia}

There are abundant receptors for arginine vasopressin (AVP), namely AVPR1 $\alpha$ and AVPR2, coupled to extracellular signal-regulated kinase (ERK) activation, on both osteoblasts and osteoclasts (Tamma et al. 2013). However, opposed to the anabolic action of OXT (Tamma et al. 2009), AVP reduces osteoblast differentiation and bone formation and enhances osteoclastogenesis and bone resorption (Tamma et al. 2013). In loss-offunction studies, the exposure of osteoblast precursors to AVPR1 $\alpha$ or AVPR2 antagonists, namely relcovaptan (SR49059) or (Adamantaneacetyl ${ }^{1}, \quad o$-Et-D-Tyr ${ }^{2}, \mathrm{Val}^{4}$, Aminobutyryl6, Arg8,9) vasopressin (ADAM), causes increased osteoblastogenesis, effects that are phenocopied in $A v p r 1 \alpha^{-/-}$mice. Osteoclast formation and bone resorption are both reduced in these mice (Tamma et al. 2013), in sum, causing a profound increase of bone mass (Tamma et al. 2013). The anabolic and anti-anabolic actions, respectively, of OXT and AVP interact, so that the increased bone mass in Avpr1 $\alpha^{-/-}$mice is reduced in compound Avpr1 $1 \alpha^{-/-}:$Oxtr-/- mutants (Sun et al. 2016). In fact, AVP and OXT can share receptors to a limited extent (Sun et al. 2016). While the OXTR is not indispensable for AVP action in inhibiting osteoblastogenesis, AVPstimulated gene expression is inhibited when the OXTR is deleted in Avpr1 $1 \alpha^{-/-}$cells. In contrast, OXT does not interact with AVPRs in vivo in a model of lactation-induced bone loss, where OXT levels are high (Sun et al. 2016).

Together, the data establish a primary role for AVP signaling in bone mass regulation. They also shed light on a long-standing dogma on the mechanism(s) of the osteoporosis that accompanies chronic hyponatremic states (Renneboog et al. 2006, Gankam Kengne et al. 2008, Sandhu et al. 2009, Kinsella et al. 2010, Verbalis et al. 2010, Barsony et al. 2011, Hoorn et al. 2011). It is quite possible that, in a case report, the documented bone loss in a patient with syndrome of inappropriate antidiuretic hormone (SIADH) had arisen from a 30 -fold elevation in serum AVP, although the accompanying high aldosterone 
could be an additional culprit (Balla et al. 1981, Chhokar et al. 2004, Carbone et al. 2008, Sejling et al. 2012). Furthermore, while AVPR2 is also expressed osteoblasts and osteoclasts, it is unlikely from our results that highly selective aquaretic AVPR2 inhibitors, such as tolvaptan, could, in fact, themselves offer osteoprotection (Hori 2013, Sun et al. 2016). AVPR1 $\alpha$ therefore appears to be the major functional skeletal receptor for AVP.

\section{Pituitary hormones and body composition}

An acute need for anti-obesity agents arises not only from the increasing population of obese individuals worldwide, currently around 600 million, but also from the relatively small armamentarium of approved anti-obesity agents that are limited by poor efficacy and unacceptable side effects. Furthermore, in women, FSH secretion begins to increase during the perimenopausal transition, preceding declines in estrogen by about 2-3 years (Sowers et al. 2003, Seifert-Klauss et al. 2012). During this period, and concurrent with the sharp decline in BMD, there is the onset of increasing visceral and bone marrow adiposity and a decrease in lean mass (Thurston et al. 2009, Wildman et al. 2012). This clinical phenotype is associated with disrupted energy metabolism and decreased physical activity (Thurston et al. 2009). Considering that FSHRs are present on bone and fat tissue (Sun et al. 2006, Cui et al. 2012, Liu et al. 2015, 2017, Feng et al. 2017), a question has arisen whether a single agent can be used to treat two aging-related medical conditions - osteoporosis and obesity - simultaneously.

We therefore utilized our polyclonal antibody to FSH $\beta$ to examine the effect of FSH blockade in mice pair-fed on a high-fat diet, ovariectomized and sham-operated mice, and mice on a normal chow, but allowed to eat ad libitum (Liu et al. 2017). In all instances, the FSH antibody prevented the development of visceral and subcutaneous obesity and induced energy-producing 'beige' adipocytes. This beiging phenotype was evident from immunolabeling for uncoupling protein 1 (UCP1), measuring the expression of Ucp1 and other brown adipose tissue (BAT) genes in white adipose tissue, and examining UCP1 expression in vivo in live UCP1 reporter, Thermo mice (Liu et al. 2017). Furthermore, the FSH antibody enhanced mitochondrial density in the photo-activatable mitochondria (PhAM) mouse and enhanced basal energy expenditure and oxygen consumption, independently of increased activity. Studies with a corresponding monoclonal FSH antibody to human FSH recapitulated the data, as did mice haploinsufficient in the Fshr. Importantly, the FSH antibody failed to prevent obesity in $F s h r^{+/}$- mice, testifying to its action via the FSH axis in vivo. Finally, there was an important, yet unexplained increase in lean mass in all groups treated with the FSH antibody. This phenotype is concordant with a strong association between reduced lean mass and high FSH levels in postmenopausal women (Gourlay et al. 2012).

TSHRs are also present in adipose tissue, although their precise function in physiology remains to be established. There is evidence from TSHR signaling-deficient hyt/ hyt mice that TSHRs may be involved in inducing lipolysis in white adipose tissue, especially in mice in a hypothyroid state (Endo \& Kobayashi 2012). Similar to the FSHR expression (Liu et al. 2017), TSHRs were induced upon differentiation of 3T3.L1 pre-adipocytes, and TSHR knockdown blocked adipocyte differentiation ( $\mathrm{Lu}$ et al. 2012). Tshr expression was also higher in visceral adipose tissues from mice fed on a high-fat diet. In humans, TSHR expression in subcutaneous adipose tissue correlated with body mass index (BMI) (Lu et al. 2012).

Epidemiologic studies support the notion that TSH is associated with an obesity phenotype. In a cross-sectional study of 194 healthy euthyroid postmenopausal women, BMI had a positive independent association with serum TSH levels (Lambrinoudaki et al. 2015). Serum TSH also correlated with BMI in a cohort of 800 hospitalized patients with BMIs of $\geq 30 \mathrm{~kg} / \mathrm{m}^{2}$ (Betry et al. 2015). Furthermore, in 60 euthyroid subjects, TSH correlated with BMI and visceral and subcutaneous adipose tissue volumes (Muscogiuri et al. 2013). Serum TSH has also been noted as being a predictor for obesity in euthyroid females. Notably, body weight, BMI, waist circumference and body fat were all found to be increased in women with serum TSH $>2.5 \mathrm{IU} / \mathrm{L}$ compared to those with TSH $\leq 2.5 \mathrm{IU} / \mathrm{L}$ (Zhang et al. 2012). Moreover, in patients with subclinical hypothyroidism who had high pretreatment serum TSH levels, but normal thyroid hormones, a significant decrease in visceral adipose tissue volume was noted following levothyroxine treatment (Akbaba et al. 2016).

With that said, several studies have failed to document correlations or shown negative correlations between serum TSH and obesity indices. Notably, a populationbased German cohort consisting of over 2000 adults aged between 20 and 79 years showed no association between serum TSH levels and visceral adipose tissue (Witte et al. 2017). In a different cohort of over 4800 patients, BMI was inversely related to higher TSH levels in patients who were classified as BAT positive upon F-18-fluordesoxyglucose 
positron emission tomography-computer tomography (FDG-PET/CT) (Brendle et al. 2018).

In addition to FSH and TSH, there is also a strong and well-documented relationship between OXT and body composition. Injection of OXT reduced body weight in mice fed both on high-fat diet or normal chow, body fat in ovariectomized mice and bone marrow fat in glucocorticoid-treated rabbits (Beranger et al. 2014, Qiu et al. 2015, Li et al. 2016, Maejima et al. 2017). Reduced OXT expression, in contrast, underscores hyperphagic obesity of single-minded 1 (Sim1) haploinsufficient mice, which are also cured upon OXT injection (Tolson et al. 2010). A cross-sectional study of women aged between 18 and 45 years further documented highest plasma OXT levels in those who were overweight or obese, with strong correlations between OXT levels and BMI and total, visceral and subcutaneous fat (Schorr et al. 2017).

However, in contrast to the peripheral action of FSH and TSH through adipose tissue GPCRs, OXT appears to act on the central nervous system to regulate body composition via a primary action on feeding. Several lines of evidence attest to this. First, unlike bone cells, there are no OXTRs yet identified in fat tissue. Second, chronic central OXT infusion in high-fat-diet-induced obese rats resulted in decreased body weight, increased adipose tissue lipolysis, increased fatty acid $\beta$-oxidation and reduced glucose intolerance and insulin resistance (Deblon et al. 2011). Third, feeding stimulated and starvation reduced OXT secretion from the pituitary (Kublaoui et al. 2008, Zhang \& Cai 2011). Fourth, patients affected by SIM1 gene mutation and by Prader-Willi syndrome, in whom hyperphagia and obesity are characteristic clinical features, displayed reduced numbers and size of OXT-ergic neurons in paraventricular nuclei (Swaab et al. 1995, Holder et al. 2000). These findings suggest that the prominent effects of OXT on body composition are mediated centrally through an effect on feeding, although there is some evidence for a peripheral action. For example, the late-onset obesity in Oxtr-/- mice is independently of daily intake of chow (Takayanagi et al. 2008). However, OXT infusion by subcutaneously implanted osmotic minipumps in dietinduced obese mice reduced food intake (Maejima et al. 2011, Morton et al. 2012). Intraperitoneal OXT injection likewise induced c-Fos expression in the hypothalamus (Maejima et al. 2011). These findings together suggest that peripherally administered OXT could cross the bloodbrain barrier and vice versa. Cell-specific conditional deletion of OXTRs in the periphery vs centrally in OXTergic neurons should provide firm conclusions regarding the primary site of action of OXT.

\section{Ubiquity of 'pituitary' hormone expression}

Not only have receptors been identified on tissues other than what are considered primary endocrine targets, 'pituitary' hormones themselves are produced in nonpituitary locations. Among the most exciting revelations has been the clear documentation of GH production in various compartments of the eye, particularly in retinal ganglion cells (Baudet et al. 2003, Harvey et al. 2004, Harvey \& Aramburo 2017, Martinez-Moreno et al. 2018). Here, they act on GHRs to regulate retinal development, and specifically, the processes of neurite outgrowth, retinal vascularization and neuronal cell proliferation and apoptosis (Harvey \& Aramburo 2017, Martinez-Moreno et al. 2018). Transgenic GH overexpression has been associated with increased axial length of the eye, whereas siRNA knockdown reduces axonal growth(Grimbly et al. 2009, Martin et al. 2011). Additionally, GH is expressed in lymphoid tissues, including thymus and spleen, as well as in both the male and female reproductive tracts (Hull \& Harvey 2014). However, apart from effects on steroidogenesis and ovarian cell proliferation, the mechanism of these extra-pituitary actions is relatively unclear.

Extra-pituitary sources of TSH have long been known (Smith et al. 1983a, Blalock 2005). In parallel with the pituitary-thyroid endocrine axis, there is additional TSHrelated circuitry that functions beyond the thyroid to involve, for example, the immune system. Immune cells, mainly macrophages, produce a novel TSH- $\beta_{\mathrm{v}}$ (Vincent et al. 2009, Baliram et al. 2013, 2016). In the mouse, the TSH- $\beta$-coding region is located in segments of exons 4 and 5 , while exon 4 is missing in mouse TSH- $\beta_{\mathrm{v}}$. In contrast, the human TSH gene contains three exonic sequences, but exon 2 is missing in the human TSH- $\beta_{\mathrm{v}}$. Molecular docking and cell-based assays show that TSH- $\beta$ and TSH- $\beta_{\mathrm{v}}$ bind to and signal through the TSHR with similar binding affinities (Baliram et al. 2013, 2016). However, while thyroid hormones suppress the production of pituitary TSH, macrophage-derived TSH- $\beta_{\mathrm{v}}$ is enhanced. Locally produced TSH- $\beta_{v}$ in response to hyperthyroidism may, in fact, offer some limited protection to the skeleton (Baliram et al. 2012), but this assumption is speculative. However, interestingly, TSH- $\beta_{\mathrm{v}}$ is also synthesized by mouse and human pituitary (Schaefer \& Klein 2009, Vincent et al. 2009). Lymphocytes are also known to express TSH (Smith et al. 1983b, Harbour et al. 1989), but there is no evidence yet for bone or marrow cell production of FSH, although co-production of TSH- $\beta$ and FSH is noted in $\mathrm{CD}_{11} \mathrm{~b}^{+}$cells from mouse thyroid (Klein \& Wang 2004). 
We have shown that Oxt, apart from its neurohypophyseal origin, is produced in abundance by both human and murine osteoblasts (Colaianni et al. 2011). Production of osteoblast Oxt is under the control of estrogen, which acts by activating the MAP kinase Erk (Colaianni et al. 2011, 2012). This non-genomic mechanism of estrogen action is in contrast to its genomic control of Oxtr expression (Tamma et al. 2009). We surmise that there is a local feed-forward loop in bone marrow through which the Oxt so produced from osteoblasts in response to estrogen acts upon its receptor to exert a potent anabolic action. We also show that the absence of Oxtrs in osteoblasts derived from Oxtr-/- mice or the attenuation of Oxtr expression in silenced cells inhibits estrogen-induced osteoblast differentiation, transcription factor upregulation and/or Oxt production in vitro. In vivo, Oxtr-/- and Col2.3-Cre+:Oxtrfl/fl mice display a bone formation defect and fail to display increases in trabecular bone volume, cortical thickness and bone formation in response to estrogen (Colaianni et al. 2012). Physiologically, therefore, feed-forward Oxt release in bone marrow by a rising estrogen concentration may facilitate rapid skeletal recovery during the latter phases of lactation.

\section{Conclusion}

The direct regulation of body composition, importantly bone mass and adipose tissue, by hormones from pituitary gland helps explain some of the inconsistencies of older models that assumed monogamous pituitary signaling through single targets. However, this latter assumption of singularity cannot be explained by highly distributed functions of primitive pituitary hormones in lower organisms. Nontraditional and important direct actions have thus emerged, which relate to effects of both anterior and posterior pituitary hormones on bone mass, body fat and energy homeostasis. Interestingly, these newly described signaling pathways appear not to have identical mechanisms to traditional endocrine targets, so that, for example, the FSHR in bone and fat tissue couples with a $G_{i}$ protein as opposed to traditional FSHR-G $\mathrm{G}_{\mathrm{s}}$ coupling in the ovarian follicular cell. There is also increasing evidence for ligands, receptors and their splice variants to be co-expressed in the same tissue, in essence, highlighting yet uncharacterized paracrine and autocrine control mechanisms. Newly discovered targets of these otherwise 'old' hormones also provide unique opportunities for the therapy of diseases that we can now attribute to changes in the levels of circulating pituitary hormones. Thus, we posit that there is a pituitary-bone and pituitary-adipose axis that, when perturbed, causes diseases, such as obesity and osteoporosis, but can be potentially utilized to target novel therapeutics for use in people.

\section{Declaration of interest}

Mone Zaidi is a named inventor of an issued US patent related to osteoclastic bone resorption filed by the Icahn School of Medicine at Mount Sinai (ISMMS). In the event the issued patent is licensed, he would be entitled to a share of any proceeds ISMMS receives from the licensee. All other authors have nothing to disclose.

\section{Funding}

Mone Zaidi, Li Sun, Terry F Davies, Harry C Blair and Clifford J Rosen are supported by grants from the National Institutes of Health. Alberta Zallone is supported by the Ministry of Education, Italy. Maria I New is supported by the Children's Hormone Research Foundation, New York, USA.

\section{References}

Abe E, Marians RC, Yu W, Wu XB, Ando T, Li Y, Iqbal J, Eldeiry L, Rajendren G, Blair HC, et al. 2003 TSH is a negative regulator of skeletal remodeling. Cell 115 151-162. (https://doi.org/10.1016/ S0092-8674(03)00771-2)

Abrahamsen B, Jorgensen HL, Laulund AS, Nybo M, Brix TH \& Hegedus L 2014 Low serum thyrotropin level and duration of suppression as a predictor of major osteoporotic fractures-the OPENTHYRO register cohort. Journal of Bone and Mineral Research 29 2040-2050. (https:// doi.org/10.1002/jbmr.2244)

Abrahamsen B, Jorgensen HL, Laulund AS, Nybo M, Bauer DC, Brix TH $\&$ Hegedus L 2015 The excess risk of major osteoporotic fractures in hypothyroidism is driven by cumulative hyperthyroid as opposed to hypothyroid time: an observational register-based time-resolved cohort analysis. Journal of Bone and Mineral Research 30 898-905. (https://doi.org/10.1002/jbmr.2416)

Acar B, Ozay AC, Ozay OE, Okyay E, Sisman AR \& Ozaksoy D 2016 Evaluation of thyroid function status among postmenopausal women with and without osteoporosis. International Journal of Gynecology and Obstetrics 134 53-57. (https://doi.org/10.1016/j.ijgo.2015.11.025)

Adami S, Bianchi G, Brandi ML, Giannini S, Ortolani S, DiMunno O, Frediani B, Rossini M \& Group Bs 2008 Determinants of bone turnover markers in healthy premenopausal women. Calcified Tissue International 82 341-347. (https://doi.org/10.1007/s00223-008-91265)

Akbaba G, Berker D, Isik S, Tuna MM, Koparal S, Vural M, Yilmaz FM, Topcuoglu C \& Guler S 2016 Changes in the before and after thyroxine treatment levels of adipose tissue, leptin, and resistin in subclinical hypothyroid patients. Wiener klinische Wochenschrift 128 579-585. (https://doi.org/10.1007/s00508-015-0865-9)

Albagha OME, Natarajan R, Reid DM \& Ralston SH 2005 The D727E polymorphism of the human thyroid stimulating hormone receptor is associated with bone mineral density and bone loss in women from the UK. Journal of Bone and Mineral Research 20 S341-S341.

Allan CM, Kalak R, Dunstan CR, McTavish KJ, Zhou H, Handelsman DJ \& Seibel MJ 2010 Follicle-stimulating hormone increases bone mass in female mice. PNAS 107 22629-22634. (https://doi.org/10.1073/ pnas.1012141108) 
Argiolas A, Collu M, Gessa GL, Melis MR \& Serra G 1988 The oxytocin antagonist d(CH2)5Tyr(Me)-Orn8-vasotocin inhibits male copulatory behaviour in rats. European Journal of Pharmacology 149 389-392. (https://doi.org/10.1016/0014-2999(88)90675-9)

Baliram R, Latif R, Berkowitz J, Frid S, Colaianni G, Sun L, Zaidi M \& Davies TF 2011 Thyroid-stimulating hormone induces a Wntdependent, feed-forward loop for osteoblastogenesis in embryonic stem cell cultures. PNAS 108 16277-16282. (https://doi.org/10.1073/ pnas.1110286108)

Baliram R, Sun L, Cao J, Li J, Latif R, Huber AK, Yuen T, Blair HC, Zaidi M \& Davies TF 2012 Hyperthyroid-associated osteoporosis is exacerbated by the loss of TSH signaling. Journal of Clinical Investigation 122 3737-3741. (https://doi.org/10.1172/JCI63948)

Baliram R, Chow A, Huber AK, Collier L, Ali MR, Morshed SA, Latif R, Teixeira A, Merad M, Liu L, et al. 2013 Thyroid and bone: macrophage-derived TSH-beta splice variant increases murine osteoblastogenesis. Endocrinology 154 4919-4926. (https://doi. org/10.1210/en.2012-2234)

Baliram R, Latif R, Morshed SA, Zaidi M \& Davies TF 2016 T3 regulates a human macrophage-derived TSH-beta splice variant: implications for human bone biology. Endocrinology 157 3658-3667. (https://doi. org/10.1210/en.2015-1974)

Balla T, Nagy K, Tarjan E, Renczes G \& Spat A 1981 Effect of reduced extracellular sodium concentration on the function of adrenal zona glomerulosa: studies in conscious rats. Journal of Endocrinology $\mathbf{8 9}$ 411-416. (https://doi.org/10.1677/joe.0.0890411)

Baqi L, Payer J, Killinger Z, Susienkova K, Jackuliak P, Cierny D \& Langer P 2010 The level of TSH appeared favourable in maintaining bone mineral density in postmenopausal women. Endocrine Regulations $\mathbf{4 4}$ 9-15. (https://doi.org/10.4149/endo_2010_01_9)

Barsony J, Sugimura Y \& Verbalis JG 2011 Osteoclast response to low extracellular sodium and the mechanism of hyponatremia-induced bone loss. Journal of Biological Chemistry 286 10864-10875. (https:// doi.org/10.1074/jbc.M110.155002)

Baudet ML, Sanders EJ \& Harvey S 2003 Retinal growth hormone in the chick embryo. Endocrinology 144 5459-5468. (https://doi. org/10.1210/en.2003-0651)

Bauer DC, Ettinger B, Nevitt MC, Stone KL \& Study of Osteoporotic Fractures Research G 2001 Risk for fracture in women with low serum levels of thyroid-stimulating hormone. Annals of Internal Medicine 134 561-568. (https://doi.org/10.7326/0003-4819-134-7-20010403000009)

Beranger GE, Pisani DF, Castel J, Djedaini M, Battaglia S, Amiaud J, Boukhechba F, Ailhaud G, Michiels JF, Heymann D, et al. 2014 Oxytocin reverses ovariectomy-induced osteopenia and body fat gain. Endocrinology 155 1340-1352. (https://doi.org/10.1210/en.2013-1688)

Beranger GE, Djedaini M, Battaglia S, Roux CH, Scheideler M, Heymann D, Amri EZ \& Pisani DF 2015 Oxytocin reverses osteoporosis in a sex-dependent manner. Frontiers in Endocrinology 6 81. (https://doi.org/10.3389/fendo.2015.00081)

Betry C, Challan-Belval MA, Bernard A, Charrie A, Drai J, Laville M, Thivolet C \& Disse E 2015 Increased TSH in obesity: evidence for a BMI-independent association with leptin. Diabetes and Metabolism 41 248-251. (https://doi.org/10.1016/j.diabet.2014.11.009)

Blair HC, Robinson LJ, Sun L, Isales C, Davies TF \& Zaidi M 2011 Skeletal receptors for steroid-family regulating glycoprotein hormones: a multilevel, integrated physiological control system. Annals of the New York Academy of Sciences 1240 26-31. (https://doi.org/10.1111/j.17496632.2011.06287.x)

Blalock JE 2005 The immune system as the sixth sense. Journal of Internal Medicine 257 126-138. (https://doi.org/10.1111/j.13652796.2004.01441.x)

Bogerd J, Granneman JC, Schulz RW \& Vischer HF 2005 Fish FSH receptors bind LH: how to make the human FSH receptor to be more fishy? General and Comparative Endocrinology 142 34-43. (https://doi. org/10.1016/j.ygcen.2004.12.008)
Brendle C, Werner MK, Schmadl M, la Fougere C, Nikolaou K, Stefan N \& Pfannenberg C 2018 Correlation of brown adipose tissue with other body fat compartments and patient characteristics: a retrospective analysis in a large patient cohort using PET/CT. Academic Radiology 25 102-110. (http://doi.org/10.1016/j.acra.2017.09.007)

Breuil V, Amri EZ, Panaia-Ferrari P, Testa J, Elabd C, AlbertSabonnadiere C, Roux CH, Ailhaud G, Dani C, Carle GF, et al. 2011 Oxytocin and bone remodelling: relationships with neuropituitary hormones, bone status and body composition. Joint Bone Spine $\mathbf{7 8}$ 611-615. (https://doi.org/10.1016/j.jbspin.2011.02.002)

Breuil V, Panaia-Ferrari P, Fontas E, Roux C, Kolta S, Eastell R, Ben Yahia H, Faure S, Gossiel F, Benhamou CL, et al. 2014 Oxytocin, a new determinant of bone mineral density in post-menopausal women: analysis of the OPUS cohort. Journal of Clinical Endocrinology and Metabolism 99 E634-E641. (https://doi.org/10.1210/jc.2013-4126)

Breuil V, Fontas E, Chapurlat R, Panaia-Ferrari P, Yahia HB, Faure S, Euller-Ziegler L, Amri EZ \& Szulc P 2015 Oxytocin and bone status in men: analysis of the MINOS cohort. Osteoporosis International 26 2877-2882. (https://doi.org/10.1007/s00198-015-3201-3)

Britto JM, Fenton AJ, Holloway WR \& Nicholson GC 1994 Osteoblasts mediate thyroid hormone stimulation of osteoclastic bone resorption. Endocrinology 134 169-176. (https://doi.org/10.1210/ endo.134.1.8275930)

Cannon JG, Cortez-Cooper M, Meaders E, Stallings J, Haddow S, Kraj B, Sloan G \& Mulloy A 2010 Follicle-stimulating hormone, interleukin-1, and bone density in adult women. American Journal of Physiology: Regulatory, Integrative and Comparative Physiology 298 R790-R798. (https://doi.org/10.1152/ajpregu.00728.2009)

Cannon JG, Kraj B \& Sloan G 2011 Follicle-stimulating hormone promotes RANK expression on human monocytes. Cytokine $\mathbf{5 3}$ 141-144. (https://doi.org/10.1016/j.cyto.2010.11.011)

Carbone LD, Cross JD, Raza SH, Bush AJ, Sepanski RJ, Dhawan S, Khan BQ, Gupta M, Ahmad K, Khouzam RN, et al. 2008 Fracture risk in men with congestive heart failure risk reduction with spironolactone. Journal of the American College of Cardiology 52 135-138. (https://doi.org/10.1016/j.jacc.2008.03.039)

Cheung E, Tsang S, Bow C, Soong C, Yeung S, Loong C, Cheung CL, Kan A, Lo S, Tam S, et al. 2011 Bone loss during menopausal transition among southern Chinese women. Maturitas 69 50-56. (https://doi.org/10.1016/j.maturitas.2011.01.010)

Chhokar VS, Sun Y, Bhattacharya SK, Ahokas RA, Myers LK, Xing Z, Smith RA, Gerling IC \& Weber KT 2004 Loss of bone minerals and strength in rats with aldosteronism. American Journal of Physiology: Heart and Circulatory Physiology 287 H2023-H2026. (https://doi. org/10.1152/ajpheart.00477.2004)

Cho SW, Bae JH, Noh GW, Kim YA, Moon MK, Park KU, Song J, Yi KH, Park do J, Chung JK, et al. 2015 The presence of thyroid-stimulation blocking antibody prevents high bone turnover in untreated premenopausal patients with Graves' disease. PLOS ONE 10 e0144599. (https://doi.org/10.1371/journal.pone.0144599)

Christy AL, D'Souza V, Babu RP, Takodara S, Manjrekar P, Hegde A \& Rukmini MS 2014 Utility of C-terminal telopeptide in evaluating levothyroxine replacement therapy-induced bone loss. Biomarker Insights 9 1-6. (https://doi.org/10.4137/BMI.S13965)

Colaianni G, Di Benedetto A, Zhu LL, Tamma R, Li J, Greco G, Peng Y, Dell'Endice S, Zhu G, Cuscito C, et al. 2011 Regulated production of the pituitary hormone oxytocin from murine and human osteoblasts. Biochemical and Biophysical Research Communications 411 512-515. (https://doi.org/10.1016/j.bbrc.2011.06.158)

Colaianni G, Sun L, Di Benedetto A, Tamma R, Zhu LL, Cao J, Grano M, Yuen T, Colucci S, Cuscito C, et al. 2012 Bone marrow oxytocin mediates the anabolic action of estrogen on the skeleton. Journal of Biological Chemistry 287 29159-29167. (https://doi.org/10.1074/jbc. M112.365049)

Colucci S, Colaianni G, Mori G, Grano M \& Zallone A 2002 Human osteoclasts express oxytocin receptor. Biochemical and Biophysical http://joe.endocrinology-journals.org

https://doi.org/10.1530/JOE-17-0680
(C) 2018 Society for Endocrinology Published by Bioscientifica Ltd. Printed in Great Britain 
Research Communications 297 442-445. (https://doi.org/10.1016/ S0006-291X(02)02009-0)

Copland JA, Ives KL, Simmons DJ \& Soloff MS 1999 Functional oxytocin receptors discovered in human osteoblasts. Endocrinology 140 4371-4374. (https://doi.org/10.1210/endo.140.9.7130)

Coss D, Yang L, Kuo CB, Xu X, Luben RA \& Walker AM 2000 Effects of prolactin on osteoblast alkaline phosphatase and bone formation in the developing rat. American Journal of Physiology: Endocrinology and Metabolism 279 E1216-E1225. (https://doi.org/10.1152/ ajpendo.2000.279.6.E1216)

Crandall CJ, Tseng CH, Karlamangla AS, Finkelstein JS, Randolph JF Jr, Thurston RC, Huang MH, Zheng H \& Greendale GA 2013 Serum sex steroid levels and longitudinal changes in bone density in relation to the final menstrual period. Journal of Clinical Endocrinology and Metabolism 98 E654-E663. (https://doi.org/10.1210/jc.2012-3651)

Cui H, Zhao G, Liu R, Zheng M, Chen J \& Wen J 2012 FSH stimulates lipid biosynthesis in chicken adipose tissue by upregulating the expression of its receptor FSHR. Journal of Lipid Research 53 909-917. (https://doi.org/10.1194/jlr.M025403)

De Jesus K, Wang X \& Liu JL 2009 A general IGF-I overexpression effectively rescued somatic growth and bone deficiency in mice caused by growth hormone receptor knockout. Growth Factors $\mathbf{2 7}$ 438-447. (https://doi.org/10.3109/08977190903299270)

Deblon N, Veyrat-Durebex C, Bourgoin L, Caillon A, Bussier AL, Petrosino S, Piscitelli F, Legros JJ, Geenen V, Foti M, et al. 2011 Mechanisms of the anti-obesity effects of oxytocin in diet-induced obese rats. PLOS ONE 6 e25565. (https://doi.org/10.1371/journal.pone.0025565)

Devleta B, Adem B \& Senada S 2004 Hypergonadotropic amenorrhea and bone density: new approach to an old problem. Journal of Bone and Mineral Metabolism 22 360-364. (https://doi.org/10.1007/s00774-0040495-1)

Di Benedetto A, Sun L, Zambonin CG, Tamma R, Nico B, Calvano CD, Colaianni G, Ji Y, Mori G, Grano M, et al. 2014 Osteoblast regulation via ligand-activated nuclear trafficking of the oxytocin receptor. PNAS 111 16502-16507. (https://doi.org/10.1073/pnas.1419349111)

Ding B, Zhang Y, Li Q, Hu Y, Tao XJ, Liu BL, Ma JH \& Li DM 2016 Low thyroid stimulating hormone levels are associated with low bone mineral density in femoral neck in elderly women. Archives of Medical Research 47 310-314. (https://doi.org/10.1016/j.arcmed.2016.07.009)

Drake MT, McCready LK, Hoey KA, Atkinson EJ \& Khosla S 2010 Effects of suppression of follicle-stimulating hormone secretion on bone resorption markers in postmenopausal women. Journal of Clinical Endocrinology and Metabolism 95 5063-5068. (https://doi.org/10.1210/ jc.2010-1103)

Elabd SK, Sabry I, Hassan WB, Nour H \& Zaky K 2007 Possible neuroendocrine role for oxytocin in bone remodeling. Endocrine Regulations 41 131-141.

Elabd C, Basillais A, Beaupied H, Breuil V, Wagner N, Scheideler M, Zaragosi LE, Massiera F, Lemichez E, Trajanoski Z, et al. 2008 Oxytocin controls differentiation of human mesenchymal stem cells and reverses osteoporosis. Stem Cells 26 2399-2407. (https://doi. org/10.1634/stemcells.2008-0127)

Endo T \& Kobayashi T 2012 Expression of functional TSH receptor in white adipose tissues of hyt/hyt mice induces lipolysis in vivo. American Journal of Physiology: Endocrinology and Metabolism 302 E1569-E1575. (https://doi.org/10.1152/ajpendo.00572.2011)

Feng Y, Zhu S, Antaris AL, Chen H, Xiao Y, Lu X, Jiang L, Diao S, Yu K, Wang Y, et al. 2017 Live imaging of follicle stimulating hormone receptors in gonads and bones using near infrared II fluorophore. Chemical Science 8 3703-3711. (https://doi.org/10.1039/C6SC04897H)

Flynn RW, Bonellie SR, Jung RT, MacDonald TM, Morris AD \& Leese GP 2010 Serum thyroid-stimulating hormone concentration and morbidity from cardiovascular disease and fractures in patients on long-term thyroxine therapy. Journal of Clinical Endocrinology and Metabolism 95 186-193. (https://doi.org/10.1210/jc.2009-1625)

Fritton JC, Emerton KB, Sun H, Kawashima Y, Mejia W, Wu Y, Rosen CJ, Panus D, Bouxsein M, Majeska RJ, et al. 2010 Growth hormone protects against ovariectomy-induced bone loss in states of low circulating insulin-like growth factor (IGF-1). Journal of Bone and Mineral Research 25 235-246. (https://doi.org/10.1359/jbmr.090723)

Gallagher CM, Moonga BS \& Kovach JS 2010 Cadmium, folliclestimulating hormone, and effects on bone in women age $42-60$ years, NHANES III. Environmental Research 110 105-111. (https://doi. org/10.1016/j.envres.2009.09.012)

Gankam Kengne F, Andres C, Sattar L, Melot C \& Decaux G 2008 Mild hyponatremia and risk of fracture in the ambulatory elderly. QJM 101 583-588. (https://doi.org/10.1093/qjmed/hcn061)

Garcia-Martin A, Reyes-Garcia R, Garcia-Castro JM, Rozas-Moreno P, Escobar-Jimenez F \& Munoz-Torres M 2012 Role of serum FSH measurement on bone resorption in postmenopausal women. Endocrine 41 302-308. (https://doi.org/10.1007/s12020-011-9541-7)

Geng W, Yan X, Du H, Cui J, Li L \& Chen F 2013 Immunization with FSHbeta fusion protein antigen prevents bone loss in a rat ovariectomy-induced osteoporosis model. Biochemical and Biophysical Research Communications 434 280-286. (https://doi.org/10.1016/j. bbrc.2013.02.116)

Gertz ER, Silverman NE, Wise KS, Hanson KB, Alekel DL, Stewart JW, Perry CD, Bhupathiraju SN, Kohut ML \& Van Loan MD 2010 Contribution of serum inflammatory markers to changes in bone mineral content and density in postmenopausal women: a 1-year investigation. Journal of Clinical Densitometry 13 277-282. (https://doi. org/10.1016/j.jocd.2010.04.003)

Gourlay ML, Preisser JS, Hammett-Stabler CA, Renner JB \& Rubin J 2011 Follicle-stimulating hormone and bioavailable estradiol are less important than weight and race in determining bone density in younger postmenopausal women. Osteoporosis International 22 2699-2708. (https://doi.org/10.1007/s00198-010-1505-x)

Gourlay ML, Specker BL, Li C, Hammett-Stabler CA, Renner JB \& Rubin JE 2012 Follicle-stimulating hormone is independently associated with lean mass but not BMD in younger postmenopausal women. Bone $\mathbf{5 0}$ 311-316. (https://doi.org/10.1016/j.bone.2011.11.001)

Grimbly C, Martin B, Karpinski E \& Harvey S 2009 Growth hormone production and action in N1E-115 neuroblastoma cells. Journal of Molecular Neuroscience 39 117-124. (https://doi.org/10.1007/s12031009-9194-7)

Grimnes G, Emaus N, Joakimsen RM, Figenschau Y \& Jorde R 2008 The relationship between serum TSH and bone mineral density in men and postmenopausal women: the Tromso study. Thyroid $\mathbf{1 8}$ 1147-1155. (https://doi.org/10.1089/thy.2008.0158)

Harbour DV, Kruger TE, Coppenhaver D, Smith EM \& Meyer WJ 3rd 1989 Differential expression and regulation of thyrotropin (TSH) in T cell lines. Molecular and Cellular Endocrinology 64 229-241. (https://doi. org/10.1016/0303-7207(89)90150-0)

Harvey S \& Aramburo C 2017 Growth hormone: not just a pituitary endocrine. Journal of Endocrine Disorders 41024.

Harvey S, Kakebeeke M \& Sanders EJ 2004 Growth hormone localization in the neural retina and retinal pigmented epithelium of embryonic chicks. Journal of Molecular Neuroscience 22 139-145. (https://doi. org/10.1385/JMN:22:1-2:139)

Hase H, Ando T, Eldeiry L, Brebene A, Peng Y, Liu L, Amano H, Davies TF, Sun L, Zaidi M, et al. 2006 TNFalpha mediates the skeletal effects of thyroid-stimulating hormone. PNAS 103 12849-12854. (https://doi. org/10.1073/pnas.0600427103)

Heemstra KA, van der Deure WM, Peeters RP, Hamdy NA, Stokkel MP, Corssmit EP, Romijn JA, Visser TJ \& Smit JW 2008 Thyroid hormone independent associations between serum TSH levels and indicators of bone turnover in cured patients with differentiated thyroid carcinoma. European Journal of Endocrinology 159 69-76. (https://doi. org/10.1530/EJE-08-0038)

Holder JL Jr, Butte NF \& Zinn AR 2000 Profound obesity associated with a balanced translocation that disrupts the SIM1 gene. Human Molecular Genetics 9 101-108. (https://doi.org/10.1093/hmg/9.1.101)

Hoorn EJ, Rivadeneira F, van Meurs JB, Ziere G, Stricker BH, Hofman A, Pols HA, Zietse R, Uitterlinden AG \& Zillikens MC 2011 Mild 
hyponatremia as a risk factor for fractures: the Rotterdam Study. Journal of Bone and Mineral Research 26 1822-1828. (https://doi. org/10.1002/jbmr.380)

Hori M 2013 Tolvaptan for the treatment of hyponatremia and hypervolemia in patients with congestive heart failure. Future Cardiology 9 163-176. (https://doi.org/10.2217/fca.13.3)

Hull KL \& Harvey S 2014 Growth hormone and reproduction: a review of endocrine and autocrine/paracrine interactions. International Journal of Endocrinology 2014 234014. (https://doi.org/10.1155/2014/234014)

Insel TR \& Harbaugh CR 1989 Lesions of the hypothalamic paraventricular nucleus disrupt the initiation of maternal behavior. Physiology and Behavior 45 1033-1041. (https://doi.org/10.1016/00319384(89)90234-5)

Iqbal J, Sun L, Kumar TR, Blair HC \& Zaidi M 2006 Follicle-stimulating hormone stimulates TNF production from immune cells to enhance osteoblast and osteoclast formation. PNAS 103 14925-14930. (https:// doi.org/10.1073/pnas.0606805103)

Isales CM, Zaidi M \& Blair HC $2010 \mathrm{ACTH}$ is a novel regulator of bone mass. Annals of the New York Academy of Sciences 1192 110-116. (https://doi.org/10.1111/j.1749-6632.2009.05231.x)

Karimifar M, Esmaili F, Salari A, Kachuei A, Faragzadegan Z \& Karimifar M 2014 Effects of levothyroxine and thyroid stimulating hormone on bone loss in patients with primary hypothyroidism. Journal of Research in Pharmacy Practice 3 83-87. (https://doi.org/10.4103/2279. 042X.141099)

Kawai H, Furuhashi M \& Suganuma N 2004 Serum follicle-stimulating hormone level is a predictor of bone mineral density in patients with hormone replacement therapy. Archives of Gynecology and Obstetrics 269 192-195. (https://doi.org/10.1007/s00404-003-0532-7)

Kim MK, Yun KJ, Kim MH, Lim DJ, Kwon HS, Song KH, Kang MI \& Baek KH 2015 The effects of thyrotropin-suppressing therapy on bone metabolism in patients with well-differentiated thyroid carcinoma. Bone 71 101-105. (https://doi.org/10.1016/j.bone.2014.10.009)

Kinsella S, Moran S, Sullivan MO, Molloy MG \& Eustace JA 2010 Hyponatremia independent of osteoporosis is associated with fracture occurrence. Clinical Journal of the American Society of Nephrology $\mathbf{5}$ 275-280. (https://doi.org/10.2215/CJN.06120809)

Klein JR \& Wang HC 2004 Characterization of a novel set of resident intrathyroidal bone marrow-derived hematopoietic cells: potential for immune-endocrine interactions in thyroid homeostasis. Journal of Experimental Biology 207 55-65. (https://doi.org/10.1242/jeb.00710)

Kobayashi T \& Andersen O 2008 The gonadotropin receptors FSH-R and LH-R of Atlantic halibut (Hippoglossus hippoglossus), 1: isolation of multiple transcripts encoding full-length and truncated variants of FSH-R. General and Comparative Endocrinology 156 584-594. (https:// doi.org/10.1016/j.ygcen.2008.02.008)

Krishnamra N \& Seemoung J 1996 Effects of acute and long-term administration of prolactin on bone $45 \mathrm{Ca}$ uptake, calcium deposit, and calcium resorption in weaned, young, and mature rats. Canadian Journal of Physiology and Pharmacology 74 1157-1165. (https://doi. org/10.1139/y96-123)

Kublaoui BM, Gemelli T, Tolson KP, Wang Y \& Zinn AR 2008 Oxytocin deficiency mediates hyperphagic obesity of Sim1 haploinsufficient mice. Molecular Endocrinology 22 1723-1734. (https://doi.org/10.1210/ me.2008-0067)

Kumar RS, Ijiri S, Kight K, Swanson P, Dittman A, Alok D, Zohar Y \& Trant JM 2000 Cloning and functional expression of a thyrotropin receptor from the gonads of a vertebrate (bony fish): potential thyroid-independent role for thyrotropin in reproduction. Molecular and Cellular Endocrinology 167 1-9. (https://doi.org/10.1016/S03037207(00)00304-X)

Kumar RS, Ijiri S \& Trant JM 2001 Molecular biology of the channel catfish gonadotropin receptors: 2. Complementary DNA cloning, functional expression, and seasonal gene expression of the folliclestimulating hormone receptor. Biology of Reproduction 65 710-717. (https://doi.org/10.1095/biolreprod65.3.710)
La Vignera S, Vicari E, Tumino S, Ciotta L, Condorelli R, Vicari LO \& Calogero AE 2008 L-thyroxin treatment and post-menopausal osteoporosis: relevance of the risk profile present in clinical history. Minerva Ginecologica 60 475-484.

Lambrinoudaki I, Armeni E, Rizos D, Georgiopoulos G, Athanasouli F, Triantafyllou N, Panoulis K, Augoulea A, Creatsa M, Alexandrou A, et al. 2015 Indices of adiposity and thyroid hormones in euthyroid postmenopausal women. European Journal of Endocrinology $\mathbf{1 7 3}$ 237-245. (https://doi.org/10.1530/EJE-15-0141)

Laron Z 1999 Natural history of the classical form of primary growth hormone (GH) resistance (Laron syndrome). Journal of Pediatric Endocrinology and Metabolism 12 (Supplement 1) 231-249.

Laron Z, Klinger B \& Silbergeld A 1999 Patients with Laron syndrome have Osteopenia/Osteoporosis. Journal of Bone and Mineral Research 14 156-157. (https://doi.org/10.1359/jbmr.1999.14.1.156)

Lawson EA, Ackerman KE, Estella NM, Guereca G, Pierce L, Sluss PM, Bouxsein ML, Klibanski A \& Misra M 2013 Nocturnal oxytocin secretion is lower in amenorrheic athletes than nonathletes and associated with bone microarchitecture and finite element analysis parameters. European Journal of Endocrinology 168 457-464. (https:// doi.org/10.1530/EJE-12-0869)

Lee SJ, Kim KM, Lee EY, Song MK, Kang DR, Kim HC, Youm Y, Yun YM, Park HY, Kim CO, et al. 2016 Low normal TSH levels are associated with impaired BMD and hip geometry in the elderly. Aging and Disease 7 734-743. (https://doi.org/10.14336/AD.2016.0325)

Li B, Jiang Y, Sun J, Liang J \& Jin Y 2016 MR spectroscopy for assessing the effects of oxytocin on marrow adipogenesis induced by glucocorticoid in rabbits. Acta Radiologica 57 701-707. (https://doi org/10.1177/0284185115599804)

Liu X, Shimono K, Zhu LL, Li J, Peng Y, Imam A, Iqbal J, Moonga S, Colaianni G, Su C, et al. 2009 Oxytocin deficiency impairs maternal skeletal remodeling. Biochemical and Biophysical Research Communications 388 161-166. (https://doi.org/10.1016/j. bbrc.2009.07.148)

Liu S, Cheng Y, Fan M, Chen D \& Bian Z 2010a FSH aggravates periodontitis-related bone loss in ovariectomized rats. Journal of Dental Research 89 366-371. (https://doi.org/10.1177/0022034509358822)

Liu S, Cheng Y, Xu W \& Bian Z $2010 b$ Protective effects of folliclestimulating hormone inhibitor on alveolar bone loss resulting from experimental periapical lesions in ovariectomized rats. Journal of Endodontics 36 658-663. (https://doi.org/10.1016/j.joen.2010.01.011)

Liu RD, Chen RX, Li WR, Huang YL, Li WH, Cai GR \& Zhang H 2012 The Glu727 allele of thyroid stimulating hormone receptor gene is associated with osteoporosis. North American Journal of Medical Sciences 4 300-304. (https://doi.org/10.4103/1947-2714.98588)

Liu XM, Chan HC, Ding GL, Cai J, Song Y, Wang TT, Zhang D, Chen H, Yu MK, Wu YT, et al. 2015 FSH regulates fat accumulation and redistribution in aging through the Galphai/Ca(2+)/CREB pathway. Aging Cell 14 409-420. (https://doi.org/10.1111/acel.12331)

Liu P, Ji Y, Yuen T, Rendina-Ruedy E, DeMambro VE, Dhawan S, AbuAmer W, Izadmehr S, Zhou B, Shin AC, et al. 2017 Blocking FSH induces thermogenic adipose tissue and reduces body fat. Nature $\mathbf{5 4 6}$ 107-112. (https://doi.org/10.1038/nature22342)

Lotinun S, Limlomwongse L \& Krishnamra N 1998 The study of a physiological significance of prolactin in the regulation of calcium metabolism during pregnancy and lactation in rats. Canadian Journal of Physiology and Pharmacology 76 218-228. (https://doi.org/10.1139/ y98-016)

Lotinun S, Limlomwongse L, Sirikulchayanonta V \& Krishnamra N 2003 Bone calcium turnover, formation, and resorption in bromocriptineand prolactin-treated lactating rats. Endocrine 20 163-170. (https:// doi.org/10.1385/ENDO:20:1-2:163)

Lu S, Guan Q, Liu Y, Wang H, Xu W, Li X, Fu Y, Gao L, Zhao J \& Wang X 2012 Role of extrathyroidal TSHR expression in adipocyte differentiation and its association with obesity. Lipids in Health and Disease 11 17. (https://doi.org/10.1186/1476-511X-11-17) 
Lukefahr AL, Frye JB, Wright LE, Marion SL, Hoyer PB \& Funk JL 2012 Decreased bone mineral density in rats rendered follicle-deplete by an ovotoxic chemical correlates with changes in follicle-stimulating hormone and inhibin A. Calcified Tissue International 90 239-249. (https://doi.org/10.1007/s00223-011-9565-2)

Ma R, Latif R \& Davies TF 2009 Thyrotropin-independent induction of thyroid endoderm from embryonic stem cells by activin A. Endocrinology 150 1970-1975. (https://doi.org/10.1210/en.2008-1374)

Ma R, Morshed S, Latif R, Zaidi M \& Davies TF 2011 The influence of thyroid-stimulating hormone and thyroid-stimulating hormone receptor antibodies on osteoclastogenesis. Thyroid 21 897-906. (https://doi.org/10.1089/thy.2010.0457)

Maejima Y, Iwasaki Y, Yamahara Y, Kodaira M, Sedbazar U \& Yada T 2011 Peripheral oxytocin treatment ameliorates obesity by reducing food intake and visceral fat mass. Aging 3 1169-1177. (https://doi. org/10.18632/aging.100408)

Maejima Y, Aoyama M, Sakamoto K, Jojima T, Aso Y, Takasu K, Takenosihita S \& Shimomura K 2017 Impact of sex, fat distribution and initial body weight on oxytocin's body weight regulation. Scientific Reports 7 8599. (https://doi.org/10.1038/s41598-017-09318-7)

Mantella RC, Vollmer RR, Li X \& Amico JA 2003 Female oxytocindeficient mice display enhanced anxiety-related behavior. Endocrinology 144 2291-2296. (https://doi.org/10.1210/en.2002-0197)

Martin BT, List EO, Kopchick JJ, Sauve Y \& Harvey S 2011 Selective inner retinal dysfunction in growth hormone transgenic mice. Growth Hormone and IGF Research 21 219-227. (https://doi.org/10.1016/j. ghir.2011.05.008)

Martinez-Moreno CG, Fleming T, Carranza M, Avila-Mendoza J, Luna M, Harvey S \& Aramburo C 2018 Growth hormone protects against kainate excitotoxicity and induces BDNF and NT3 expression in chicken neuroretinal cells. Experimental Eye Research 166 1-12. (https://doi.org/10.1016/j.exer.2017.10.005)

Martini G, Gennari L, De Paola V, Pilli T, Salvadori S, Merlotti D, Valleggi F, Campagna S, Franci B, Avanzati A, et al. 2008 The effects of recombinant TSH on bone turnover markers and serum osteoprotegerin and RANKL levels. Thyroid 18 455-460. (https://doi. org/10.1089/thy.2007.0166)

Mazziotti G, Sorvillo F, Piscopo M, Cioffi M, Pilla P, Biondi B, Iorio S, Giustina A, Amato G \& Carella C 2005 Recombinant human TSH modulates in vivo C-telopeptides of type-1 collagen and bone alkaline phosphatase, but not osteoprotegerin production in postmenopausal women monitored for differentiated thyroid carcinoma. Journal of Bone and Mineral Research 20 480-486. (https://doi.org/10.1359/JBMR.041126)

Mazziotti G, Porcelli T, Patelli I, Vescovi PP \& Giustina A 2010 Serum TSH values and risk of vertebral fractures in euthyroid post-menopausal women with low bone mineral density. Bone 46 747-751. (https://doi. org/10.1016/j.bone.2009.10.031)

Meaney AM, Smith S, Howes OD, O’Brien M, Murray RM \& O'Keane V 2004 Effects of long-term prolactin-raising antipsychotic medication on bone mineral density in patients with schizophrenia. British Journal of Psychiatry 184 503-508. (https://doi.org/10.1192/ bjp.184.6.503)

Meher BR, Dixit A, Bousfield GR \& Lushington GH 2015 Glycosylation effects on FSH-FSHR interaction dynamics: a case study of different FSH glycoforms by molecular dynamics simulations. PLOS ONE 10 e0137897. (https://doi.org/10.1371/journal.pone.0137897)

Menagh PJ, Turner RT, Jump DB, Wong CP, Lowry MB, Yakar S, Rosen CJ \& Iwaniec UT 2010 Growth hormone regulates the balance between bone formation and bone marrow adiposity. Journal of Bone and Mineral Research 25 757-768. (https://doi.org/10.1359/jbmr.091015)

Mendoza N, Quereda F, Presa J, Salamanca A, Sanchez-Borrego R, Vazquez F \& Martinez Astorquiza T 2012 Estrogen-related genes and postmenopausal osteoporosis risk. Climacteric 15 587-593. (https:// doi.org/10.3109/13697137.2012.656160)

Mikosch P, Kerschan-Schindl K, Woloszczuk W, Stettner H, Kudlacek S, Kresnik E, Gallowitsch HJ, Lind P \& Pietschmann P 2008 High cathepsin $\mathrm{K}$ levels in men with differentiated thyroid cancer on suppressive L-thyroxine therapy. Thyroid 18 27-33. (https://doi. org/10.1089/thy.2007.0186)

Morris MS 2007 The association between serum thyroid-stimulating hormone in its reference range and bone status in postmenopausal American women. Bone 40 1128-1134. (https://doi.org/10.1016/j. bone.2006.12.001)

Morton GJ, Thatcher BS, Reidelberger RD, Ogimoto K, Wolden-Hanson T, Baskin DG, Schwartz MW \& Blevins JE 2012 Peripheral oxytocin suppresses food intake and causes weight loss in diet-induced obese rats. American Journal of Physiology: Endocrinology and Metabolism 302 E134-E144. (https://doi.org/10.1152/ajpendo.00296.2011)

Muscogiuri G, Sorice GP, Mezza T, Prioletta A, Lassandro AP, Pirronti T, Della Casa S, Pontecorvi A \& Giaccari A 2013 High-normal TSH values in obesity: is it insulin resistance or adipose tissue's guilt? Obesity 21 101-106. (https://doi.org/10.1002/oby.20240)

Naylor KE, Iqbal P, Fledelius C, Fraser RB \& Eastell R 2000 The effect of pregnancy on bone density and bone turnover. Journal of Bone and Mineral Research 15 129-137. (https://doi.org/10.1359/ jbmr.2000.15.1.129)

Nishimori K, Young LJ, Guo Q, Wang Z, Insel TR \& Matzuk MM 1996 Oxytocin is required for nursing but is not essential for parturition or reproductive behavior. PNAS 93 11699-11704. (https://doi. org/10.1073/pnas.93.21.11699)

Noh HM, Park YS, Lee J \& Lee W 2015 A cross-sectional study to examine the correlation between serum TSH levels and the osteoporosis of the lumbar spine in healthy women with normal thyroid function. Osteoporosis International 26 997-1003. (https://doi.org/10.1007/ s00198-014-2906-z)

Novack DV 2003 TSH, the bone suppressing hormone. Cell 115 129-130. (https://doi.org/10.1016/S0092-8674(03)00812-2)

Pallinger E \& Csaba G 2008 A hormone map of human immune cells showing the presence of adrenocorticotropic hormone, triiodothyronine and endorphin in immunophenotyped white blood cells. Immunology 123 584-589. (https://doi.org/10.1111/j.13652567.2007.02731.x)

Podfigurna-Stopa A, Pludowski P, Jaworski M, Lorenc R, Genazzani AR \& Meczekalski B 2012 Skeletal status and body composition in young women with functional hypothalamic amenorrhea. Gynecological Endocrinology 28 299-304. (https://doi.org/10.3109/09513590.2011. 613972)

Qiu Y, Yao J, Wu X, Zhou B, Shao H, Hua T, Xiong Z \& Tang G 2015 Longitudinal assessment of oxytocin efficacy on bone and bone marrow fat masses in a rabbit osteoporosis model through 3.0-T magnetic resonance spectroscopy and micro-CT. Osteoporosis International 26 1081-1092. (https://doi.org/10.1007/s00198-014-2933-9)

Randolph JF Jr, Sowers M, Gold EB, Mohr BA, Luborsky J, Santoro N, McConnell DS, Finkelstein JS, Korenman SG, Matthews KA, et al. 2003 Reproductive hormones in the early menopausal transition relationship to ethnicity, body size, and menopausal status. Journal of Clinical Endocrinology and Metabolism 88 1516-1522. (https://doi. org/10.1210/jc.2002-020777)

Rendina D, Gianfrancesco F, De Filippo G, Merlotti D, Esposito T, Mingione A, Nuti R, Strazzullo P, Mossetti G \& Gennari L 2010 FSHR gene polymorphisms influence bone mineral density and bone turnover in postmenopausal women. European Journal of Endocrinology 163 165-172. (https://doi.org/10.1530/EJE-10-0043)

Renneboog B, Musch W, Vandemergel X, Manto MU \& Decaux G 2006 Mild chronic hyponatremia is associated with falls, unsteadiness, and attention deficits. American Journal of Medicine 119 e71-e78. (https:// doi.org/10.1016/j.amjmed.2006.05.019)

Ritter V, Thuering B, Saint Mezard P, Luong-Nguyen NH, Seltenmeyer Y, Junker U, Fournier B, Susa M \& Morvan F 2008 Follicle-stimulating hormone does not impact male bone mass in vivo or human male osteoclasts in vitro. Calcified Tissue International 82 383-391. (https:// doi.org/10.1007/s00223-008-9134-5) 
Robinson LJ, Tourkova I, Wang Y, Sharrow AC, Landau MS, Yaroslavskiy BB, Sun L, Zaidi M \& Blair HC 2010 FSH-receptor isoforms and FSH-dependent gene transcription in human monocytes and osteoclasts. Biochemical and Biophysical Research Communications 394 12-17. (https://doi.org/10.1016/j.bbrc.2010.02.112)

Sampath TK, Simic P, Sendak R, Draca N, Bowe AE, O’Brien S, Schiavi SC, McPherson JM \& Vukicevic S 2007 Thyroid-stimulating hormone restores bone volume, microarchitecture, and strength in aged ovariectomized rats. Journal of Bone and Mineral Research 22 849-859. (https://doi.org/10.1359/jbmr.070302)

Sandhu HS, Gilles E, DeVita MV, Panagopoulos G \& Michelis MF 2009 Hyponatremia associated with large-bone fracture in elderly patients. International Urology and Nephrology 41 733-737. (https://doi. org/10.1007/s11255-009-9585-2)

Schaefer JS \& Klein JR 2009 A novel thyroid stimulating hormone betasubunit isoform in human pituitary, peripheral blood leukocytes, and thyroid. General and Comparative Endocrinology 162 241-244. (https:// doi.org/10.1016/j.ygcen.2009.04.006)

Schorr M, Marengi DA, Pulumo RL, Yu E, Eddy KT, Klibanski A, Miller KK \& Lawson EA 2017 Oxytocin and its relationship to body composition, bone mineral density, and hip geometry across the weight spectrum. Journal of Clinical Endocrinology and Metabolism 102 2814-2824. (https://doi.org/10.1210/jc.2016-3963)

Sclafani A, Rinaman L, Vollmer RR \& Amico JA 2007 Oxytocin knockout mice demonstrate enhanced intake of sweet and nonsweet carbohydrate solutions. American Journal of Physiology: Regulatory, Integrative and Comparative Physiology 292 R1828-R1833. (https://doi. org/10.1152/ajpregu.00826.2006)

Seifert-Klauss V, Fillenberg S, Schneider H, Luppa P, Mueller D \& Kiechle M 2012 Bone loss in premenopausal, perimenopausal and postmenopausal women: results of a prospective observational study over 9 years. Climacteric 15 433-440. (https://doi.org/10.3109/136971 37.2012.658110)

Sejling AS, Pedersen-Bjergaard U \& Eiken P 2012 Syndrome of inappropriate $\mathrm{ADH}$ secretion and severe osteoporosis. Journal of Clinical Endocrinology and Metabolism 97 4306-4310. (https://doi. org/10.1210/jc.2012-2031)

Seriwatanachai D, Charoenphandhu N, Suthiphongchai T \& Krishnamra N 2008a Prolactin decreases the expression ratio of receptor activator of nuclear factor kappaB ligand/osteoprotegerin in human fetal osteoblast cells. Cell Biology International 32 1126-1135. (https://doi.org/10.1016/j.cellbi.2008.04.026)

Seriwatanachai D, Thongchote K, Charoenphandhu N, Pandaranandaka J, Tudpor K, Teerapornpuntakit J, Suthiphongchai T \& Krishnamra N 2008b Prolactin directly enhances bone turnover by raising osteoblast-expressed receptor activator of nuclear factor kappaB ligand/osteoprotegerin ratio. Bone 42 535-546. (https://doi. org/10.1016/j.bone.2007.11.008)

Smith EM, Phan M, Kruger TE, Coppenhaver DH \& Blalock JE $1983 a$ Human lymphocyte production of immunoreactive thyrotropin. PNAS 80 6010-6013. (https://doi.org/10.1073/pnas.80.19.6010)

Smith EM, Phan M, Kruger TE, Coppenhaver DH \& Blalock JE $1983 b$ Human lymphocyte production of immunoreactive thyrotropin. PNAS 80 6010-6013. (https://doi.org/10.1073/pnas.80.19.6010)

Sowers M, Eyre D, Hollis BW, Randolph JF, Shapiro B, Jannausch ML \& Crutchfield M 1995 Biochemical markers of bone turnover in lactating and nonlactating postpartum women. Journal of Clinical Endocrinology and Metabolism 80 2210-2216. (https://doi.org/10.1210/ jcem.80.7.7608281)

Sowers MR, Greendale GA, Bondarenko I, Finkelstein JS, Cauley JA, Neer RM \& Ettinger B 2003 Endogenous hormones and bone turnover markers in pre- and perimenopausal women: SWAN. Osteoporosis International 14 191-197. (https://doi.org/10.1007/s00198-002-1329-4)

Su XY, Zou X, Chen QZ, Zeng YH, Shao Y, He BC \& Liu H 2017 Folliclestimulating hormone beta-subunit potentiates bone morphogenetic protein 9-induced osteogenic differentiation in mouse embryonic fibroblasts. Journal of Cellular Biochemistry 118 1792-1802. (https:// doi.org/10.1002/jcb.25849)

Sun L, Peng Y, Sharrow AC, Iqbal J, Zhang Z, Papachristou DJ, Zaidi S, Zhu LL, Yaroslavskiy BB, Zhou H, et al. 2006 FSH directly regulates bone mass. Cell 125 247-260. (https://doi.org/10.1016/j. cell.2006.01.051)

Sun L, Vukicevic S, Baliram R, Yang G, Sendak R, McPherson J, Zhu LL, Iqbal J, Latif R, Natrajan A, et al. 2008 Intermittent recombinant TSH injections prevent ovariectomy-induced bone loss. PNAS $\mathbf{1 0 5}$ 4289-4294. (https://doi.org/10.1073/pnas.0712395105)

Sun L, Zhang Z, Zhu LL, Peng Y, Liu X, Li J, Agrawal M, Robinson LJ, Iqbal J, Blair HC, et al. 2010 Further evidence for direct pro-resorptive actions of FSH. Biochemical and Biophysical Research Communications 394 6-11. (https://doi.org/10.1016/j.bbrc.2010.02.113)

Sun L, Zhu LL, Lu P, Yuen T, Li J, Ma R, Baliram R, Moonga SS, Liu P, Zallone A, et al. 2013 Genetic confirmation for a central role for TNFalpha in the direct action of thyroid stimulating hormone on the skeleton. PNAS 110 9891-9896. (https://doi.org/10.1073/ pnas.1308336110)

Sun L, Tamma R, Yuen T, Colaianni G, Ji Y, Cuscito C, Bailey J, Dhawan S, Lu P, Calvano CD, et al. 2016 Functions of vasopressin and oxytocin in bone mass regulation. PNAS 113 164-169. (https://doi. org/10.1073/pnas.1523762113)

Svare A, Nilsen TI, Bjoro T, Forsmo S, Schei B \& Langhammer A 2009 Hyperthyroid levels of TSH correlate with low bone mineral density: the HUNT 2 study. European Journal of Endocrinology 161 779-786. (https://doi.org/10.1530/EJE-09-0139)

Swaab DF, Purba JS \& Hofman MA 1995 Alterations in the hypothalamic paraventricular nucleus and its oxytocin neurons (putative satiety cells) in Prader-Willi syndrome: a study of five cases. Journal of Clinical Endocrinology and Metabolism 80 573-579. (https://doi.org/10.1210/ jcem.80.2.7852523)

Takayanagi Y, Kasahara Y, Onaka T, Takahashi N, Kawada T \& Nishimori K 2008 Oxytocin receptor-deficient mice developed late-onset obesity. Neuroreport 19 951-955. (https://doi.org/10.1097/ WNR.0b013e3283021ca9)

Tamma R, Colaianni G, Zhu LL, DiBenedetto A, Greco G, Montemurro G, Patano N, Strippoli M, Vergari R, Mancini L, et al. 2009 Oxytocin is an anabolic bone hormone. PNAS 106 7149-7154. (https://doi. org/10.1073/pnas.0901890106)

Tamma R, Sun L, Cuscito C, Lu P, Corcelli M, Li J, Colaianni G, Moonga SS, Di Benedetto A, Grano M, et al. 2013 Regulation of bone remodeling by vasopressin explains the bone loss in hyponatremia. PNAS 110 18644-18649. (https://doi.org/10.1073/pnas.1318257110)

Thurston RC, Sowers MR, Sternfeld B, Gold EB, Bromberger J, Chang Y, Jofefe H, Crandall CJ, Waetjen LE \& Matthews KA 2009 Gains in body fat and vasomotor symptom reporting over the menopausal transition: the study of women's health across the nation. American Journal of Epidemiology 170 766-774. (https://doi.org/10.1093/aje/ kwp203)

Tolson KP, Gemelli T, Gautron L, Elmquist JK, Zinn AR \& Kublaoui BM 2010 Postnatal Sim1 deficiency causes hyperphagic obesity and reduced Mc4r and oxytocin expression. Journal of Neuroscience 30 3803-3812. (https://doi.org/10.1523/JNEUROSCI.5444-09.2010)

Tourkova IL, Witt MR, Li L, Larrouture Q, Liu L, Luo J, Robinson LJ \& Blair HC 2015 Follicle stimulating hormone receptor in mesenchymal stem cells integrates effects of glycoprotein reproductive hormones. Annals of the New York Academy of Sciences 1335 100-109. (https://doi. org/10.1111/nyas.12502)

van der Deure WM, Uitterlinden AG, Hofman A, Rivadeneira F, Pols HA, Peeters RP \& Visser TJ 2008 Effects of serum TSH and FT4 levels and the TSHR-Asp727Glu polymorphism on bone: the Rotterdam Study. Clinical Endocrinology 68 175-181. (https://doi.org/10.1111/j.13652265.2007.03016.x)

van Rijn LE, Pop VJ \& Williams GR 2014 Low bone mineral density is related to high physiological levels of free thyroxine in peri- 
menopausal women. European Journal of Endocrinology 170 461-468. (https://doi.org/10.1530/EJE-13-0769)

Verbalis JG, Barsony J, Sugimura Y, Tian Y, Adams DJ, Carter EA \& Resnick HE 2010 Hyponatremia-induced osteoporosis. Journal of Bone and Mineral Research 25 554-563. (https://doi.org/10.1359/ jbmr.090827)

Vibede N, Hauser F, Williamson M \& Grimmelikhuijzen CJ 1998 Genomic organization of a receptor from sea anemones, structurally and evolutionarily related to glycoprotein hormone receptors from mammals. Biochemical and Biophysical Research Communications 252 497-501. (https://doi.org/10.1006/bbrc.1998.9661)

Vincent BH, Montufar-Solis D, Teng BB, Amendt BA, Schaefer J \& Klein JR 2009 Bone marrow cells produce a novel TSHbeta splice variant that is upregulated in the thyroid following systemic virus infection. Genes and Immunity 10 18-26. (https://doi.org/10.1038/gene.2008.69)

Wang B, Song Y, Chen Y, Wang ES, Zheng D, Qu F \& Zhou JH 2015a Correlation analysis for follicle-stimulating hormone and C-terminal cross-linked telopetides of type i collagen in menopausal transition women with osteoporosis. International Journal of Clinical and Experimental Medicine 8 2417-2422.

Wang J, Zhang W, Yu C, Zhang X, Zhang H, Guan Q, Zhao J \& Xu J $2015 b$ Follicle-stimulating hormone increases the risk of postmenopausal osteoporosis by stimulating osteoclast differentiation. PLOS ONE 10 e0134986. (https://doi.org/10.1371/journal.pone.0134986)

Wang LY, Smith AW, Palmer FL, Tuttle RM, Mahrous A, Nixon IJ, Patel SG, Ganly I, Fagin JA \& Boucai L 2015c Thyrotropin suppression increases the risk of osteoporosis without decreasing recurrence in ATA lowand intermediate-risk patients with differentiated thyroid carcinoma. Thyroid 25 300-307. (https://doi.org/10.1089/thy.2014.0287)

Wang M, Lan L, Li T, Li J \& Li Y 2016 The effect of oxytocin on osseointegration of titanium implant in ovariectomized rats. Connective Tissue Research 57 220-225. (https://doi.org/10.3109/03008 207.2016.1141902)

Waring AC, Harrison S, Fink HA, Samuels MH, Cawthon PM, Zmuda JM, Orwoll ES, Bauer DC \& Osteoporotic Fractures in Men S 2013 A prospective study of thyroid function, bone loss, and fractures in older men: the MrOS study. Journal of Bone and Mineral Research $\mathbf{2 8}$ 472-479. (https://doi.org/10.1002/jbmr.1774)

Wildman RP, Tepper PG, Crawford S, Finkelstein JS, Sutton-Tyrrell K, Thurston RC, Santoro N, Sternfeld B \& Greendale GA 2012 Do changes in sex steroid hormones precede or follow increases in body weight during the menopause transition? Results from the Study of Women's Health Across the Nation. Journal of Clinical Endocrinology and Metabolism 97 E1695-E1704. (https://doi.org/10.1210/jc.20121614)

Witte T, Volzke H, Lerch MM, Hegenscheid K, Friedrich N, Ittermann T \& Batsis JA 2017 Association between serum thyroid-stimulating hormone levels and visceral adipose tissue: a population-based study in Northeast Germany. European Thyroid Journal 6 12-19. (https://doi. org/10.1159/000450977)

Wu Y, Torchia J, Yao W, Lane NE, Lanier LL, Nakamura MC \& Humphrey MB 2007 Bone microenvironment specific roles of ITAM adapter signaling during bone remodeling induced by acute estrogendeficiency. PLOS ONE 2 e586. (https://doi.org/10.1371/journal. pone.0000586)

Wu XY, Wu XP, Xie H, Zhang H, Peng YQ, Yuan LQ, Su X, Luo XH \& Liao EY 2010 Age-related changes in biochemical markers of bone turnover and gonadotropin levels and their relationship among
Chinese adult women. Osteoporosis International 21 275-285. (https:// doi.org/10.1007/s00198-009-0943-9)

Wysolmerski JJ 2002 The evolutionary origins of maternal calcium and bone metabolism during lactation. Journal of Mammary Gland Biology and Neoplasia 7 267-276.

Xu ZR, Wang AH, Wu XP, Zhang H, Sheng ZF, Wu XY, Xie H, Luo XH \& Liao EY 2009 Relationship of age-related concentrations of serum FSH and LH with bone mineral density, prevalence of osteoporosis in native Chinese women. Clinica Chimica Acta 400 8-13. (https://doi. org/10.1016/j.cca.2008.09.027)

Yakar S, Rosen CJ, Beamer WG, Ackert-Bicknell CL, Wu Y, Liu JL, Ooi GT, Setser J, Frystyk J, Boisclair YR, et al. 2002 Circulating levels of IGF-1 directly regulate bone growth and density. Journal of Clinical Investigation 110 771-781. (https://doi.org/10.1172/JCI0215463)

Yamoah K, Brebene A, Baliram R, Inagaki K, Dolios G, Arabi A, Majeed R, Amano H, Wang R, Yanagisawa R, et al. 2008 High-mobility group box proteins modulate tumor necrosis factor-alpha expression in osteoclastogenesis via a novel deoxyribonucleic acid sequence. Molecular Endocrinology 22 1141-1153. (https://doi.org/10.1210/ me.2007-0460)

Young WS 3rd, Shepard E, DeVries AC, Zimmer A, LaMarca ME, Ginns EI, Amico J, Nelson RJ, Hennighausen L \& Wagner KU 1998 Targeted reduction of oxytocin expression provides insights into its physiological roles. Advances in Experimental Medicine and Biology 449 231-240.

Zaidi M 2007 Skeletal remodeling in health and disease. Nature Medicine 13 791-801. (https://doi.org/10.1038/nm1593)

Zaidi M, Sun L, Davies TF \& Abe E 2006 Low TSH triggers bone loss: fact or fiction? Thyroid 16 1075-1076. (https://doi.org/10.1089/ thy.2006.16.1075)

Zaidi M, Sun L, Robinson LJ, Tourkova IL, Liu L, Wang Y, Zhu LL, Liu X, Li J, Peng Y, et al. 2010 ACTH protects against glucocorticoidinduced osteonecrosis of bone. PNAS 107 8782-8787. (https://doi. org/10.1073/pnas.0912176107)

Zallone A 2006 Direct and indirect estrogen actions on osteoblasts and osteoclasts. Annals of the New York Academy of Sciences 1068 173-179. (https://doi.org/10.1196/annals.1346.019)

Zhang G \& Cai D 2011 Circadian intervention of obesity development via resting-stage feeding manipulation or oxytocin treatment. American Journal of Physiology: Endocrinology and Metabolism 301 E1004-E1012. (https://doi.org/10.1152/ajpendo.00196.2011)

Zhang J, Sun H, Chen L, Zheng J, Hu X, Wang S \& Chen T 2012 Relationship between serum TSH level with obesity and NAFLD in euthyroid subjects. Journal of Huazhong University of Science and Technology: Medical Sciences 32 47-52. (https://doi.org/10.1007/ s11596-012-0008-8)

Zhu LL, Blair H, Cao J, Yuen T, Latif R, Guo L, Tourkova IL, Li J, Davies TF, Sun L, et al. 2012a Blocking antibody to the beta-subunit of FSH prevents bone loss by inhibiting bone resorption and stimulating bone synthesis. PNAS 109 14574-14579. (https://doi.org/10.1073/ pnas.1212806109)

Zhu LL, Tourkova I, Yuen T, Robinson LJ, Bian Z, Zaidi M \& Blair HC $2012 b$ Blocking FSH action attenuates osteoclastogenesis. Biochemical and Biophysical Research Communications 422 54-58. (https://doi. org/10.1016/j.bbrc.2012.04.104)

Zofkova I \& Hill M 2008 Biochemical markers of bone remodeling correlate negatively with circulating TSH in postmenopausal women. Endocrine Regulations 42 121-127.

Received in final form 5 March 2018

Accepted 19 March 2018

Accepted Preprint published online 19 March 2018 http://joe.endocrinology-journals.org https://doi.org/10.1530/JOE-17-0680 (c) 2018 Society for Endocrinology Published by Bioscientifica Ltd. Printed in Great Britain 